\title{
Effect of Base Sequence and Hydration on the Electronic and Hole Transport Properties of Duplex DNA: Theory and Experiment ${ }^{\dagger}$
}

\author{
Robert N. Barnett, $₫$ Charles L. Cleveland,, Uzi Landman, $*, \$$ Edna Boone, $\$$ \\ Sriram Kanvah, ${ }^{\S}$ and Gary B. Schuster*, $\$$ \\ Schools of Physics and of Chemistry and Biochemistry, Georgia Institute of Technology, \\ Atlanta, Georgia 30332
}

Received: October 11, 2002; In Final Form: November 22, 2002

\begin{abstract}
An experimental investigation and theoretical study of the duplex DNA sequences d( $5^{\prime}$-GAGG- $\left.3^{\prime}\right)$ $\mathrm{d}\left(3^{\prime}-\mathrm{CTCC}-5^{\prime}\right)$ and $\mathrm{d}\left(5^{\prime}-\mathrm{GTGG}-3^{\prime}\right) \cdot \mathrm{d}\left(3^{\prime}-\mathrm{CACC}-5^{\prime}\right)$ was carried out. The experiments show that the efficiency of radical cation transport, revealed by strand cleavage after treatment with piperidine, is the same in both sequences. Density functional theory (DFT) calculations reveal essentially identical ionization potentials and hole distributions for these sequences when they are properly hydrated. The effect of hydration on the electronic properties of these sequences was examined theoretically. Calculations on dry DNA (i.e., having no water molecules) gives "phantom" electronic transitions to orbitals associated with the sodium counterions. However, these transitions vanish even with a minimal level of hydration. Meaningful theoretical results for DNA are obtained only when the counterions and hydrating water molecules are properly considered.
\end{abstract}

\section{Introduction}

Long-distance charge transport in duplex DNA oligonucleotides in solution is an area of intense experimental and theoretical investigation. Radical cations ("holes") introduced into DNA by any one of several means can migrate long distances (tens or hundreds of angstroms) before being trapped by a reaction with water or oxygen. ${ }^{1-4}$ Trapping of the radical cation occurs most frequently at the guanine of $\mathrm{G} \cdot \mathrm{C}$ base pairs, and reaction is particularly favorable at the $5^{\prime}$-terminus of $(\mathrm{G} \cdot \mathrm{C})_{n}$ sequences $(n=2,3)$. This reaction causes oxidative damage at guanine, which can lead to dangerous mutations. ${ }^{5}$

The mechanism for charge migration in duplex DNA is currently under active consideration. In broad terms, the proposed mechanisms fall into three categories: (i) A coherent single-step tunneling processes with charge localized only on the initial and final states. ${ }^{6}$ If this mechanism operates, it is expected to confer "wire-like" properties to the DNA, which is a possibility that now seems doubtful. ${ }^{7-10}$ (ii) An incoherent random-walk multistep hopping reaction between initial and final states, where hops between sequential guanines (hole "resting sites") are mediated by superexchange across intervening $\mathrm{A} \cdot \mathrm{T}$ and $\mathrm{T} \cdot \mathrm{A}$ base pairs that can be thought of as bridges. ${ }^{11}$ (iii) A process referred to as a polaron-like hopping mechanism where local energy-lowering dynamical structural distortions generate a self-trapped state of the radical cation having a finite spatial extent, and thermally activated hopping transports the polaron from one location to another. ${ }^{4}$

The four common aromatic bases of natural DNA $(\mathrm{G}, \mathrm{C}, \mathrm{A}$, and $\mathrm{T}$ ) can be arranged in limitless combinations to generate unique sequence patterns. Obviously, it is important to understand how a particular sequence of base pairs affects the rate and efficiency of long-distance charge migration in DNA

\footnotetext{
$\dagger$ Part of the special issue "George S. Hammond \& Michael Kasha Festschrift",

School of Physics.

$\S$ School of Chemistry and Biochemistry.
}

because these effects will certainly help to reveal the chargetransfer mechanism. In an experiment that incorporated the duplex fragment $\mathrm{d}\left(5^{\prime}-\mathrm{GGAAAGG}-3^{\prime}\right) \cdot \mathrm{d}\left(3^{\prime}-\mathrm{CCTTTCC}-5^{\prime}\right)$ as a probe in a longer DNA sequence, we showed that the $(A \cdot T)_{3}$ spacer (bridge) does not introduce a significant barrier for radical cation migration between the $(\mathrm{G} \cdot \mathrm{C})_{2}$ steps. ${ }^{12}$ More recently, Giese et al. ${ }^{13}$ showed that the probe sequences $(\mathrm{A} \cdot \mathrm{T})_{4}$ and $(A \cdot T)_{16}$ as bridges between a $G \cdot C$ and a $(G \cdot C)_{3}$ step impose similar barriers to the charge migration despite their striking difference in length. However, for short sequences that contain mixed $\mathrm{A} \cdot \mathrm{T}$ and $\mathrm{T} \cdot \mathrm{A}$ base pairs, such as d(5'-GATTGGG-3') $\mathrm{d}\left(3^{\prime}\right.$-CTAACCC-5'), Giese and co-workers find that the efficiency of radical cation transport between $\mathrm{G} \cdot \mathrm{C}$ and $(\mathrm{G} \cdot \mathrm{C})_{3}$ decreases about 10 times for each intervening $\mathrm{A} \cdot \mathrm{T}$ or $\mathrm{T} \cdot \mathrm{A}$ base pair. ${ }^{14}$ Lewis and Wasielewski and co-workers, ${ }^{15}$ using timeresolved spectroscopy and kinetic modeling, report that the rate constant for charge transport from $\mathrm{G} \cdot \mathrm{C}$ to $(\mathrm{G} \cdot \mathrm{C})_{2}$ in the probe sequence $\mathrm{d}\left(5^{\prime}-\mathrm{GAGG}-3^{\prime}\right) \cdot \mathrm{d}\left(3^{\prime}-\mathrm{CTCC}-5^{\prime}\right)$ is about 40 times larger than for the sequence $d\left(5^{\prime}-\mathrm{GTGG}-3^{\prime}\right) \cdot \mathrm{d}\left(3^{\prime}-\mathrm{CACC}-5^{\prime}\right)$, which differs only by the conversion of one $\mathrm{A} \cdot \mathrm{T}$ base pair to $\mathrm{T} \cdot \mathrm{A}$. In longer DNA oligomers that contain several $(\mathrm{G} \cdot \mathrm{C})_{n}$ steps and a variable number of intervening $A \cdot T$ and $T \cdot A$ base pairs, experiments that utilize relative reaction efficiency to assess the efficiency of charge migration show a shallow distance dependence that is only modestly affected by $\mathrm{A} \cdot \mathrm{T}$ and $\mathrm{T} \cdot \mathrm{A}$ base pairs. ${ }^{3,16,17}$ Remarkably, Barton and co-workers ${ }^{18}$ report that the relative reactivity of the $(\mathrm{G} \cdot \mathrm{C})_{2}$ steps that are incorporated in the duplex fragment $\mathrm{d}\left[5^{\prime}-\mathrm{CCG}(\mathrm{T})_{8} \mathrm{GCC}-3^{\prime}\right] \cdot \mathrm{d}\left[3^{\prime}-\mathrm{GGC}(\mathrm{A})_{8}-\right.$ CGG- $\left.5^{\prime}\right]$ is nearly the same as it is for the mixed-sequence probe $\mathrm{d}\left[5^{\prime}-\mathrm{CCG}(\mathrm{TA})_{4} \mathrm{GCC}-3^{\prime}\right] \cdot \mathrm{d}\left[3^{\prime}-\mathrm{GGC}(\mathrm{AT})_{4} \mathrm{CGG}-5^{\prime}\right]$. This finding is in striking contrast to a factor of 10 decrease for each intervening $\mathrm{A} \cdot \mathrm{T}$ base pair reported by Giese and co-workers ${ }^{14}$ from relative reactivity data and a factor of 40 decrease in the rate constant for hole transport caused by changing a single $\mathrm{A} \cdot \mathrm{T}$ base pair to $\mathrm{T} \cdot \mathrm{A}$ obtained by Lewis and Wasielewski and co-workers ${ }^{15}$ from the modeling of kinetic data. 
SCHEME 1: Mechanism for Anthraquinone-Photosensitized One-Electron Oxidation of DNA ${ }^{a}$

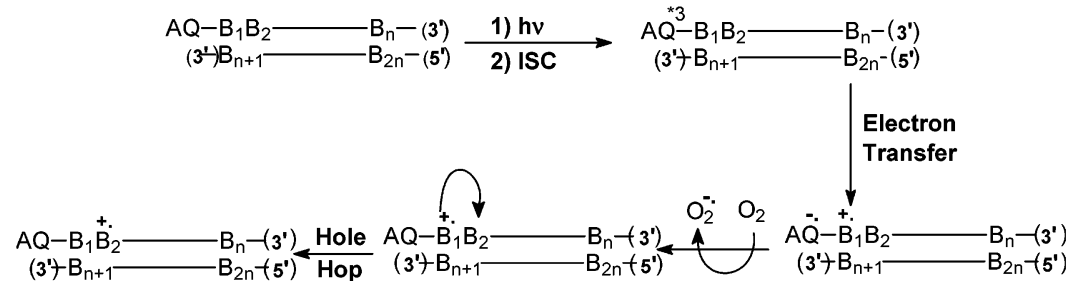

${ }^{a}$ Bases 1 through $n$ are on the AQ-containing strand; bases $(n+1)$ through $2 n$ are on the complementary strand. The AQ is attached to a 5 -terminus of the DNA.

\section{CHART 1: Structure of the DNA Oligomers}

AQ-DNA(1)

AQ-5'A A A T G C C G G G T A C C T T C T A G G C C G T A G

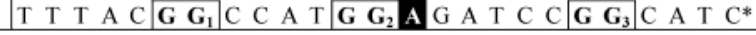

AQ-DNA(2)

AQ-5'-A A A T G C C G G T A C C A $\mathbf{A}$ C T A G G C C G T A G

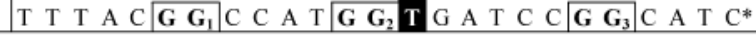
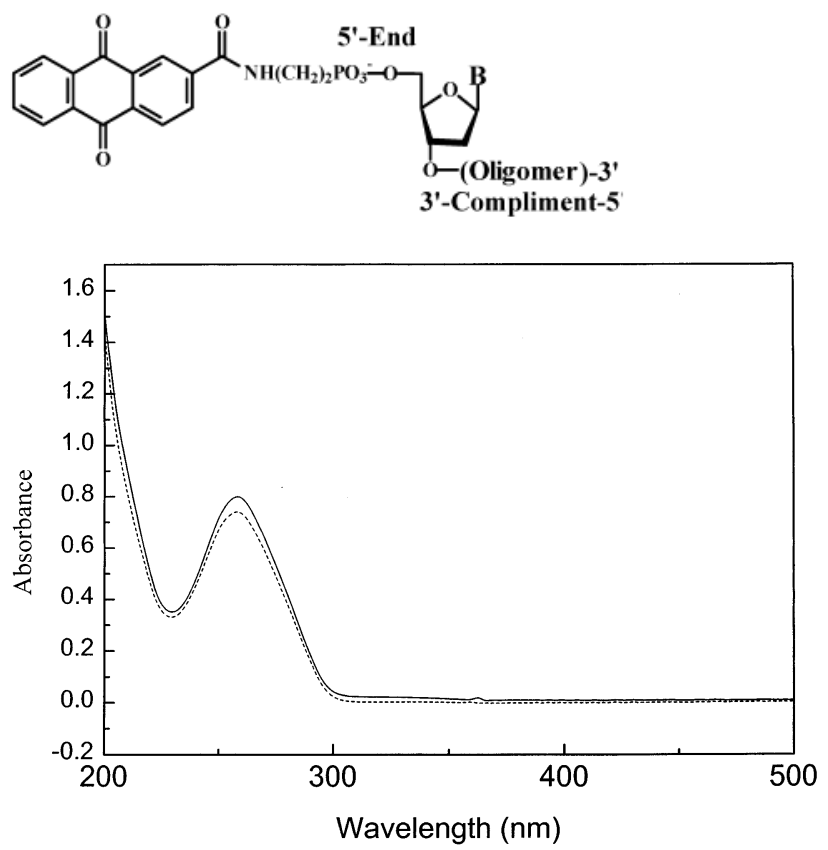

Figure 1. Electronic absorption spectra of AQ-DNA(1) and AQ-DNA(2) measured in aqueous buffer solution $(10 \mathrm{mM}$ sodium phosphate at $\mathrm{pH}$ 7.0) at room temperature. The concentration of the DNA samples (ca. $5 \mu \mathrm{M}$ ) is too low to permit observation of the $\mathrm{n} \pi^{*}$ absorptions of the anthraquinone group; only the stronger $\pi \pi^{*}$ absorptions are seen.

In a thoughtful theoretical investigation of the electronic coupling between static DNA bases for estimation of the chargetransfer rates, Voityuk et al. ${ }^{19}$ calculate that an intervening $\mathrm{T} \cdot \mathrm{A}$ base pair will show enhanced efficiency compared with an intervening $\mathrm{A} \cdot \mathrm{T}$ for the superexchange-induced hopping between $\mathrm{G} \cdot \mathrm{C}$ base pairs (see, however, ref 20 ). ${ }^{20}$ In particular, the ratio of the rates for hole hopping from $\mathrm{G} \cdot \mathrm{C}$ to $\mathrm{G} \cdot \mathrm{C}$ in the sequence $\mathrm{d}\left(5^{\prime}-\mathrm{GTTG}-3^{\prime}\right) \cdot \mathrm{d}\left(3^{\prime}-\mathrm{CAAC}-5^{\prime}\right)$ is estimated to be 10 times that of $\mathrm{d}\left(5^{\prime}-\mathrm{GTAG}-3^{\prime}\right) \cdot \mathrm{d}\left(3^{\prime}-\mathrm{CATC}-5^{\prime}\right)$ and 5 times that of $\mathrm{d}\left(5^{\prime}-\mathrm{GATG}-3^{\prime}\right) \cdot \mathrm{d}\left(3^{\prime}-\mathrm{CTAC}-5^{\prime}\right)$, which is consistent with some experimental findings of Giese and co-workers. ${ }^{14}$ However, Troisi and Orlandi ${ }^{21}$ recently reported a study of the effect of dynamic distortions away from the canonical static B-form DNA structure on the effective electronic coupling between bases and find that it fluctuates from its mean value by more than an order of magnitude over a $40 \mathrm{ps}$ interval. Since the estimated lifetime for hole hopping from $\mathrm{G} \cdot \mathrm{C}$ to $(\mathrm{G} \cdot \mathrm{C})_{2}$ in the probe sequence $\mathrm{d}\left(5^{\prime}-\mathrm{GAGG}-3^{\prime}\right) \cdot \mathrm{d}\left(3^{\prime}-\mathrm{CTCC}-5^{\prime}\right)$ is ca. $100 \mathrm{~ns},{ }^{15}$ it seems certain

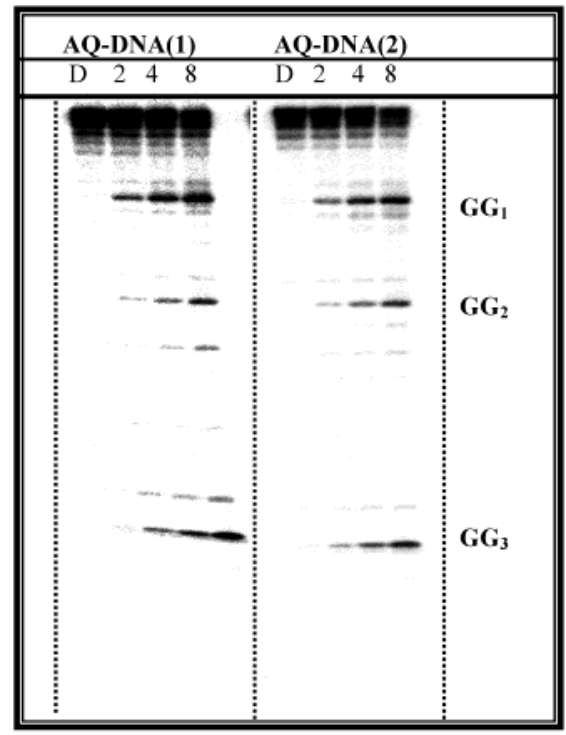

Figure 2. Autoradiograms of irradiated AQ-DNA(1) and AQ-DNA(2) that show strand cleavage after treatment with piperidine. All samples were irradiated with $4 \times 350 \mathrm{~nm}$ Rayonet lamps at ca. $30{ }^{\circ} \mathrm{C}$ in $10 \mathrm{mM}$ sodium phosphate buffer solution at $\mathrm{pH}$ 7.0. The headings for each lane stand for 0 min (dark control), 2, 4, and $8 \mathrm{~min}$ of irradiation. The cleavage at the GG steps is labeled; reaction at the $5^{\prime}-\mathrm{G}$ dominates and cleavage at the $3^{\prime}-\mathrm{G}$ is barely visible at this exposure of the radiolabeled gel.

TABLE 1: Relative Reactivities of $(C \cdot G)_{2}$ Steps in AQ-DNA(1) and AQ-DNA(2)

\begin{tabular}{cccc}
\hline sequence & $\mathrm{GG}_{1} / \mathrm{GG}_{1}$ & $\mathrm{GG}_{1} / \mathrm{GG}_{2}$ & $\mathrm{GG}_{1} / \mathrm{GG}_{3}$ \\
\hline AQ-DNA(1) & $\equiv 1.00^{a}$ & $2.1 \pm 0.1$ & $2.1 \pm 0.2$ \\
AQ-DNA(2) & $\equiv 1.00$ & $2.3 \pm 0.2$ & $2.4 \pm 0.2$
\end{tabular}

${ }^{a}$ Ratios of strand cleavage at $5^{\prime}-\mathrm{G}_{n}$ to $5^{\prime}-\mathrm{G}_{1}$ measured by phosphorimagery.

that electron coupling matrix elements calculated for static B-form DNA are not suitable models for DNA oligonucleotides in solution.

We recently reported the results of a combined experimental and theoretical study of the probe sequence d(5'-GAGG-3') $\mathrm{d}\left(3^{\prime}-\mathrm{CTCC}-5^{\prime}\right)$ that showed the necessity of including the sugarphosphate backbone, solvating water molecules, and neutralizing counterions in models of charge transport in DNA. ${ }^{22}$ This study revealed that the ionization potential of this sequence and the localization of the radical cation are strongly modulated by the location of the $\mathrm{Na}^{+}$counterions. These findings led to a model for hole hopping where the rate is controlled, in part, by the probability of forming certain counterion configurations that are effective in changing the hole density over the duplex DNA sequence. We report here an extension of that study to the examination of the effect that converting a $\mathrm{T} \cdot \mathrm{A}$ base pair to $\mathrm{A} \cdot \mathrm{T}$ has on the efficiency of radical cation migration, determined experimentally, and on the ionization potential and charge 


$$
\mathrm{d}(\mathrm{GAGG})+6 \mathrm{Na}^{+}+\mathrm{n}\left(\mathrm{H}_{2} \mathrm{O}\right)
$$
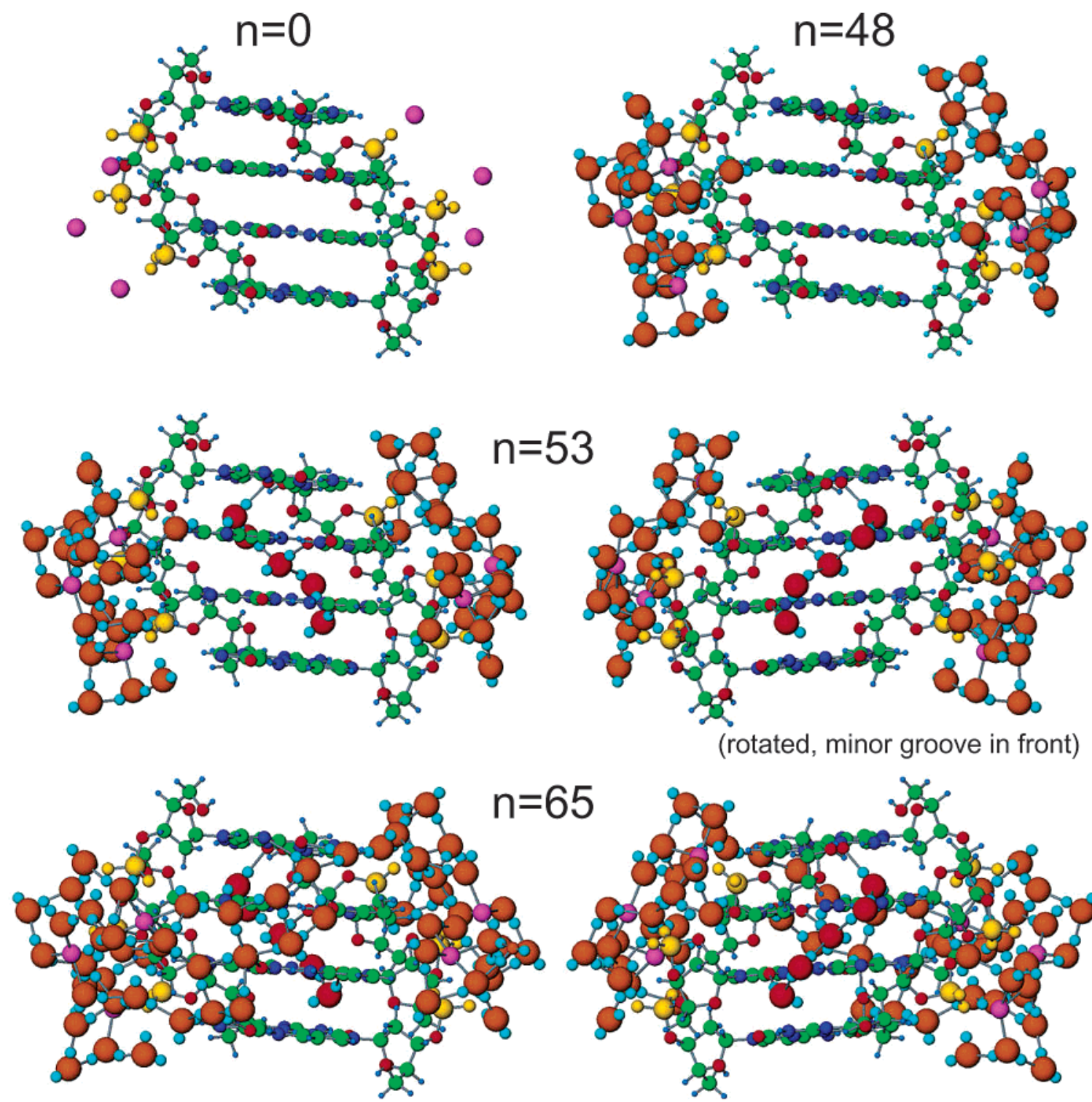

(rotated, minor groove in front)
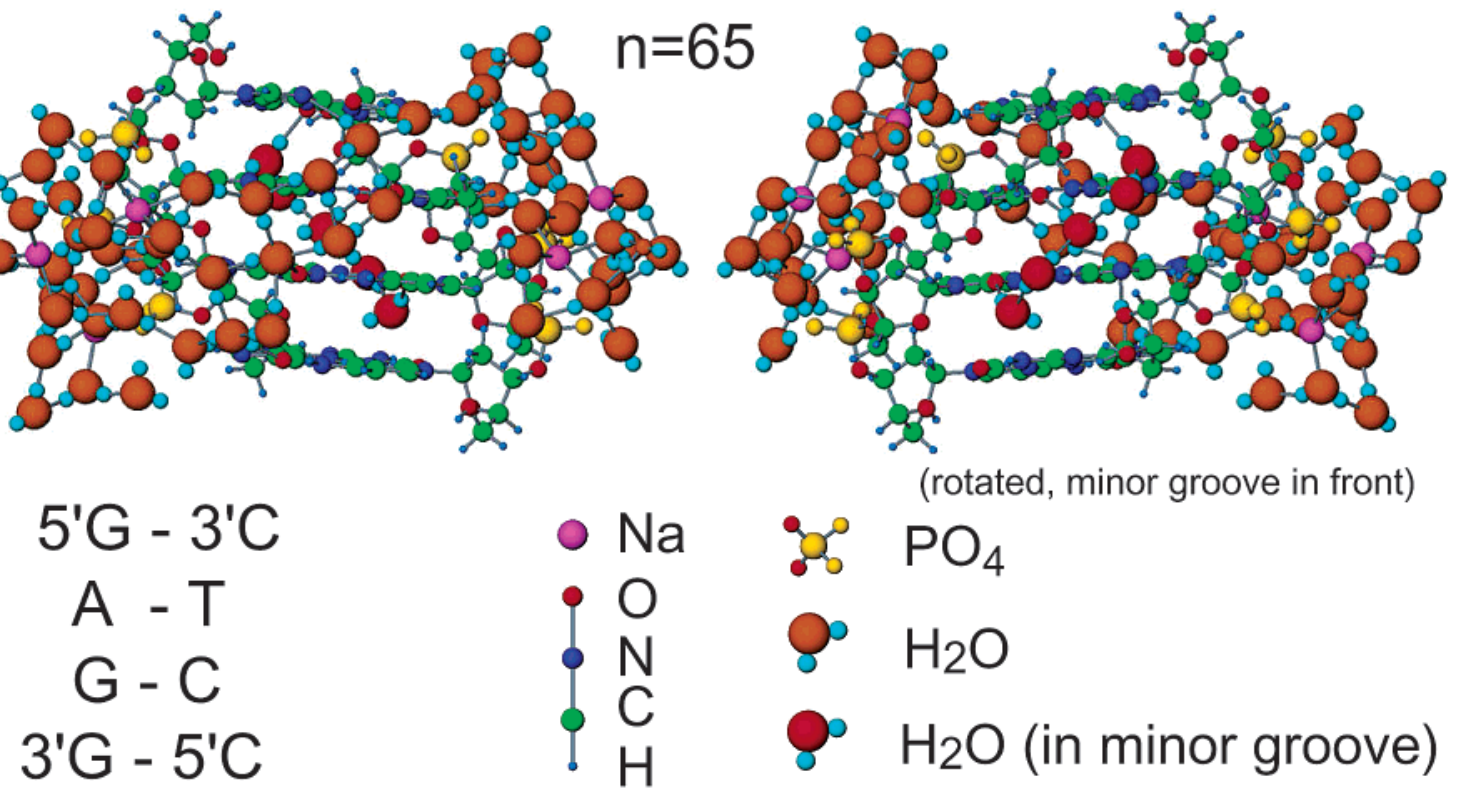

(rotated, minor groove in front)

Figure 3. Atomic configurations of $\mathrm{d}\left(5^{\prime}\right.$-GAGG-3') $\mathrm{d}\left(3^{\prime}-\mathrm{CTCC}-5^{\prime}\right)+6 \mathrm{Na}^{+}+n\left(\mathrm{H}_{2} \mathrm{O}\right)$, prepared as described in the text, with $\mathrm{Na}^{+}$located in the vicinity of the sugar-phosphate groups of the DNA backbone The following systems are shown: (i) $n=0$, that is, an unhydrated duplex; (ii) $n$ $=48$, where the water molecules hydrate the backbone (including the sodium counterions) of the DNA oligomer; (iii) $n=53$, where in addition to the hydration of the sugar-phosphate backbone, five additional $\mathrm{H}_{2} \mathrm{O}$ molecules hydrate the minor groove of the DNA duplex; and (iv) $n=65$, where further hydration of the DNA major groove (involving 12 additional water molecules) is considered. For $n=53$ and $n=65$ we show two views, rotated with respect to each other by $180^{\circ}$ about the double helix axis. The colors corresponding to the various atoms are displayed in the figure.

delocalization, which were determined computationally. Importantly, we also use first-principle quantum mechanical calculations to examine the effect of hydration on the electronic and spectral properties of these probe oligomers. Both experiment and theory indicate that there is virtually no change in ionization potential or hole transport properties when the $\mathrm{T} \cdot \mathrm{A}$ base pair is converted to $\mathrm{A} \cdot \mathrm{T}$. In contrast, the electronic and spectral properties of these DNA segments are shown by calculations to be remarkably sensitive to hydration.

\section{Materials and Methods}

Experimental Methods. (A) General Information. Oligodeoxyribonucleotides were prepared by standard solid-phase methods and purified by reverse-phase HPLC. The anthraqui- 


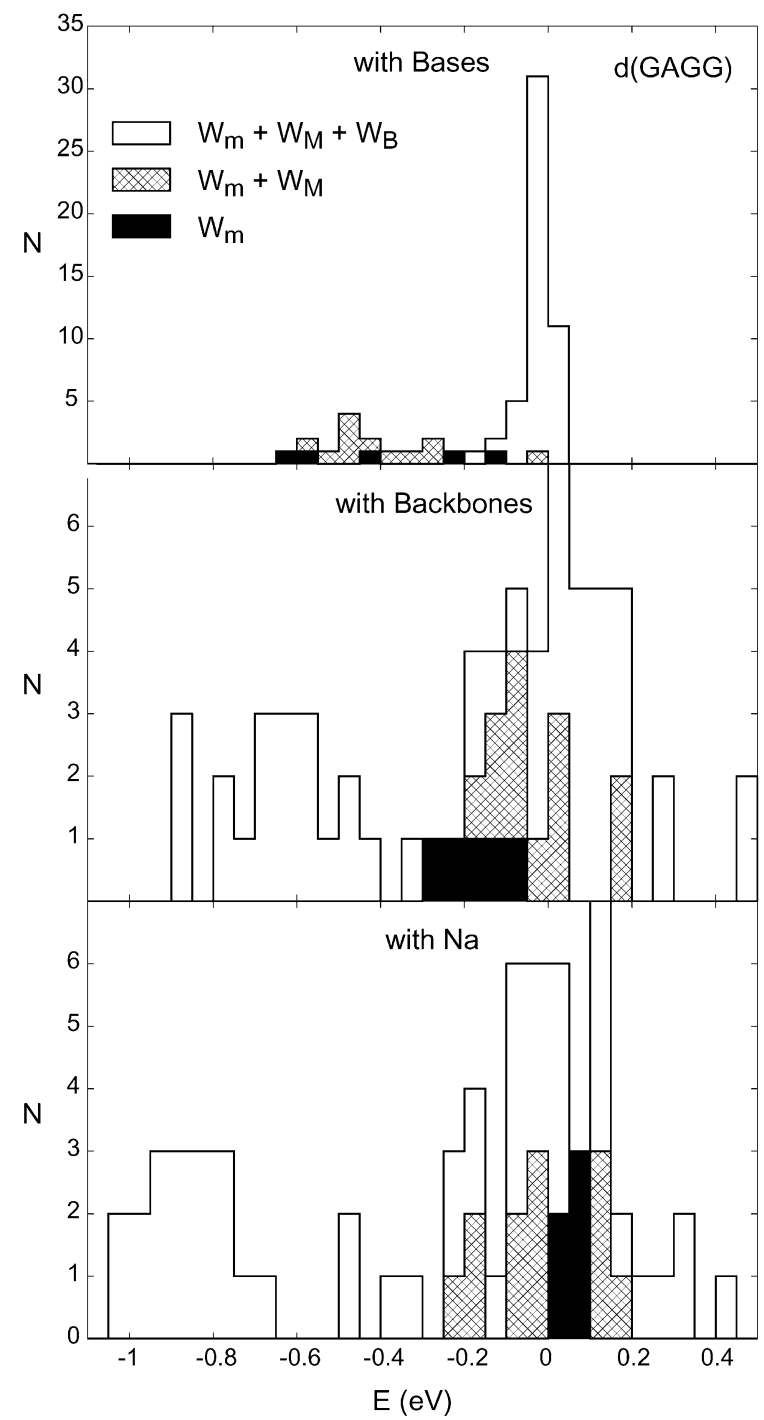

Figure 4. Histograms of the distributions of the interaction energies between the $\mathrm{H}_{2} \mathrm{O}$ molecules and the various components of the $\mathrm{d}\left(5^{\prime}\right.$-GAGG-3') $\mathrm{d}\left(3^{\prime}-\mathrm{CTCC}-5^{\prime}\right)$ duplex. Contributions coming from interactions with the DNA bases are shown in the top panel, those with the sugar-phosphate backbones in the middle panel, and the interactions with the sodium counterions are displayed in the bottom panel. Contributions due to water molecules hydrating the minor and major grooves are denoted by $\mathrm{W}_{\mathrm{m}}$ and $\mathrm{W}_{\mathrm{M}}$, respectively, and those associated with water molecules hydrating the sugar-phosphate backbones and counterions are denoted by $\mathrm{W}_{\mathrm{B}}$.

none phosphoramidite was synthesized as described previously. ${ }^{12}$ The buffer used in all DNA experiments was $10 \mathrm{mM}$ sodium phosphate at $\mathrm{pH}$ 7.0. The concentrations of the purified oligomers were determined by optical spectroscopy at $260 \mathrm{~nm}$.

(B) Preparation of Radiolabeled DNA. ${ }^{32} \mathrm{P}-5$ '-end-labeling was accomplished with T4 polynucleotide kinase and $\left[\gamma-{ }^{32} \mathrm{P}\right]-$ dATP. DNA strands $(5.0 \mu \mathrm{M})$ were incubated with $2.0 \mu \mathrm{L}$ of $\left[\gamma_{-}{ }^{32} \mathrm{P}\right] \mathrm{dATP}(6000 \mathrm{Ci} / \mathrm{mmol})$ and $1.0 \mu \mathrm{L}$ of T4 polynucleotide kinase in a total volume of $30 \mu \mathrm{L}$ at $37{ }^{\circ} \mathrm{C}$ for $45 \mathrm{~min}$. After incubation, the labeled DNA was suspended in denaturing loading buffer and purified on a $20 \%$ denaturing polyacrylamide gel. Labeled product was located by autoradiography. Bands corresponding to the DNA product were excised from the gel and eluted with $750 \mu \mathrm{L}$ of elution buffer [0.5 $\mathrm{M} \mathrm{NH}_{4} \mathrm{OAc}, 10.0$ $\mathrm{mM} \mathrm{Mg}(\mathrm{OAc})_{2}, 1.0 \mathrm{mM}$ EDTA, and $\left.0.1 \% \mathrm{SDS}\right]$ at $37{ }^{\circ} \mathrm{C}$ for $4 \mathrm{~h}$. The supernatant from each sample was extracted and centrifuged at $12000 \mathrm{~g}$ for $0.5 \mathrm{~min}$. Precipitation proceeded by addition of $1.0 \mu \mathrm{L}$ of glycogen and $700 \mu \mathrm{L}$ of cold absolute

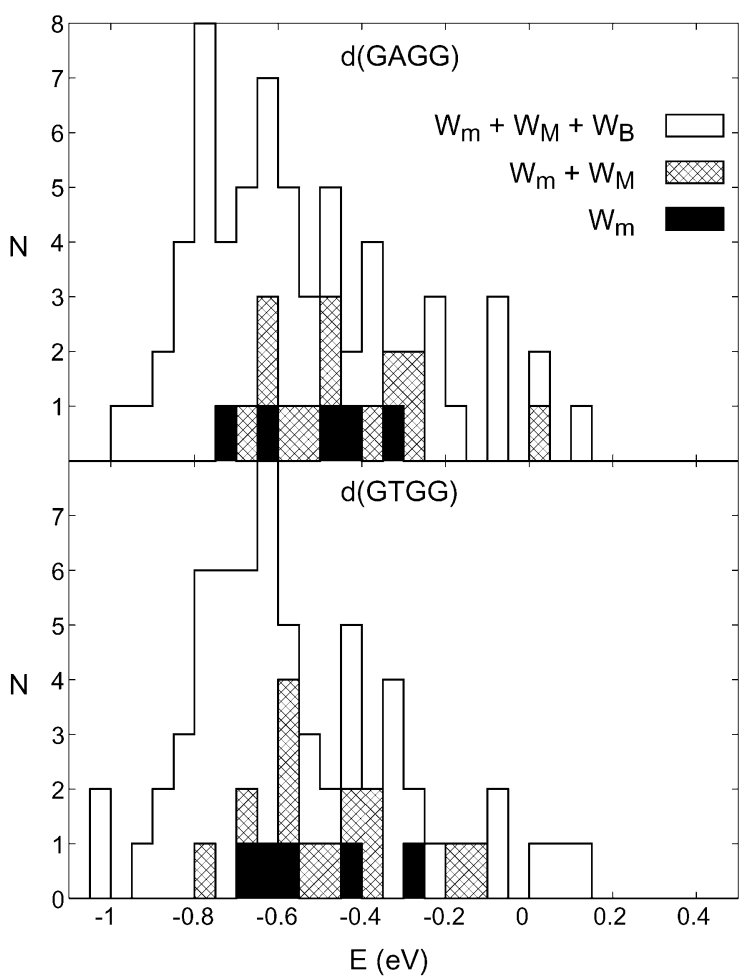

Figure 5. Histograms of the distributions of the total hydration interaction energies (excluding interwater interactions) between the $\mathrm{H}_{2} \mathrm{O}$ molecules and the d(5'-GAGG-3') $\cdot \mathrm{d}\left(3^{\prime}-\mathrm{CTCC}-5^{\prime}\right)$ (top panel) and $\mathrm{d}\left(5^{\prime}-\mathrm{GTGG}-3^{\prime}\right) \cdot \mathrm{d}\left(3^{\prime}-\mathrm{CACC}-5^{\prime}\right)$ (bottom panel) duplexes. Contributions from various regions of the hydration environment are distinguished: Those due to water molecules hydrating the minor and major grooves are denoted by $\mathrm{W}_{\mathrm{m}}$ and $\mathrm{W}_{\mathrm{M}}$, respectively, and those associated with water molecules hydrating the sugar-phosphate backbones and counterions are denoted by $\mathrm{W}_{\mathrm{B}}$.

ethanol. The mixtures were mixed on an agitator, placed on dry ice for $45 \mathrm{~min}$ to complete precipitation, and centrifuged for $30 \mathrm{~min}$ at $12000 \mathrm{~g}$ in a Savant $\mu$ SpeedFuge centrifuge. The supernatant was discarded. The resulting DNA pellets were washed twice at room temperature with $80 \%$ ethanol and dried with a Savant Speed Vac Plus for $45 \mathrm{~min}$. The dried pellets were reconstituted in buffer solution, hybridized on a thermocycler at $90{ }^{\circ} \mathrm{C}$ for $5.0 \mathrm{~min}$, and slowly cooled to room temperature over a 4-h period.

(C) Photolysis and Analysis. Samples for irradiation were prepared by incubating $5.0 \mu \mathrm{M}$ of unlabeled strands with labeled complementary $(5000 \mathrm{cpm})$ strand in $70 \mu \mathrm{L}$ of buffer solution. Samples were irradiated in $1.5 \mu \mathrm{L}$ microcentrifuge tubes by use of a Rayonet Photoreactor equipped with $350 \mathrm{~nm}$ lamps. The extent of reaction was kept below $10 \%$ in all cases and "singlehit" conditions were confirmed by examination of the effect of irradiation time. When the irradiation was complete, an aliquot was withdrawn for piperidine treatment and a second portion was removed for direct precipitation. Piperidine treatment consisted of adding $1 \mathrm{M}(100 \mu \mathrm{L})$ of piperidine to each sample. The samples were mixed with an agitator for $15 \mathrm{~s}$, heated at 90 ${ }^{\circ} \mathrm{C}$ for $30 \mathrm{~min}$, and placed in a to a Savant Speed Vac Plus. The samples were dried for $1 \mathrm{~h}$ at medium heat. To ensure that all of the piperidine was removed, $20 \mu \mathrm{L}$ of water was added to each sample and the drying process was repeated. This waterwash procedure was performed twice. Dried samples were dissolved in $5.0 \mu \mathrm{L}$ of denaturing formamide-loading buffer. The photocleavage products were separated electrophoretically on a $20 \%$ polyacrylamide sequencing gel and detected by autoradiography after drying for $2.0 \mathrm{~h}$ on a Hoefer Drygel $\mathrm{Sr}$ SE1160 Dryer. 

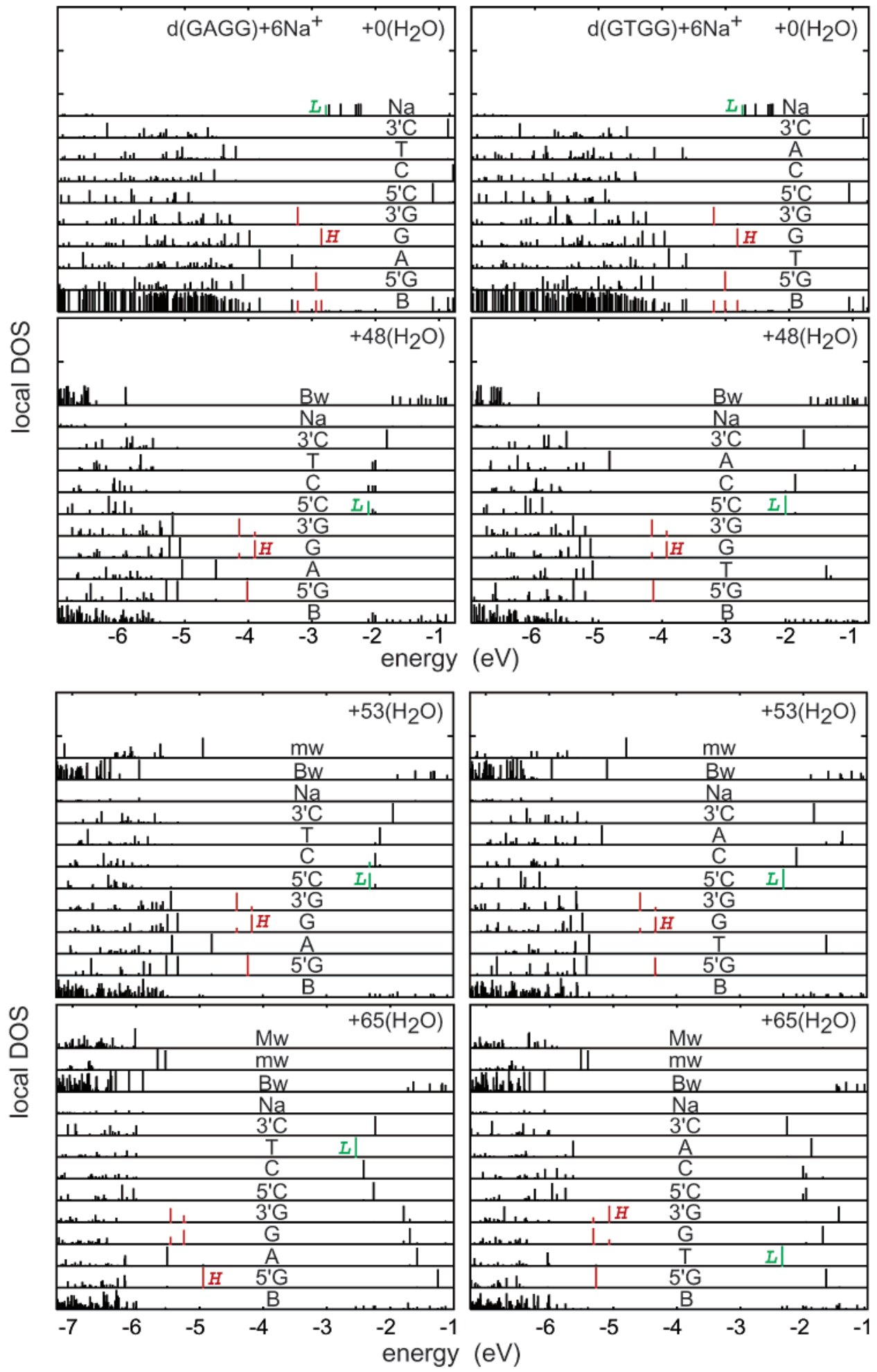

Figure 6. Local densities of states (LDOS) of the electronic eigenvalue spectra for various hydration levels $\left[n\left(\mathrm{H}_{2} \mathrm{O}\right)=0,45\right.$, 53, and 65] of the $\mathrm{d}\left(5^{\prime}-\mathrm{GAGG}-3^{\prime}\right) \cdot \mathrm{d}\left(3^{\prime}-\mathrm{CTCC}-5^{\prime}\right)$ and $\mathrm{d}\left(5^{\prime}-\mathrm{GTGG}-3^{\prime}\right) \cdot \mathrm{d}\left(3^{\prime}-\mathrm{CACC}-5^{\prime}\right)$ oligomers. The plots provide information about the weights of orbitals (corresponding to electronic levels with energies at a given range) at various spatial regions, i.e., the heights of the vertical bars at the various energies (on the horizontal axis) indicate the probabilities of finding electrons that occupy these orbitals at particular spatial regions of the DNA, including the nuclear bases (marked by the first letter of their chemical names and their location in the duplex, when applicable, i.e., 5'G, A, G, 3'G, etc.; the sugar-phosphate backbone (B); the $\mathrm{Na}^{+}$counterions; and the water molecules in the minor groove $\left(\mathrm{W}_{\mathrm{m}}\right)$, those in the major groove $\left(\mathrm{W}_{\mathrm{M}}\right)$, and those hydrating the sugar-phosphate backbone and counterions $\left(\mathrm{W}_{\mathrm{B}}\right)$. The highest occupied molecular orbitals $(\mathrm{HOMO})$ are marked in red, and the lowest unoccupied molecular orbital (LUMO) is marked in green.

Theoretical Methods and Modeling Procedure. (A) Classical Molecular Mechanics and Molecular Dynamics. The atomistic model configurations of the DNA oligomers $\mathrm{d}\left(5^{\prime}\right.$ GAGG-3') $\mathrm{d}\left(3^{\prime}-\mathrm{CTCC}-5^{\prime}\right)$ and $\mathrm{d}\left(5^{\prime}-\mathrm{GTGG}-3^{\prime}\right) \cdot \mathrm{d}\left(3^{\prime}-\mathrm{CACC}-5^{\prime}\right)$ duplexes, at various hydration levels, used in the quantum mechanical calculations of the electronic and spectral properties were prepared by use of the Amber 6 program suite, ${ }^{23}$ employing the Amber 95 potentials. ${ }^{24}$ In such modeling, the system was initially created by constructing a B-DNA oligomer of sequence $\mathrm{d}\left(5^{\prime}-\mathrm{GAGG}-3^{\prime}\right) \cdot \mathrm{d}\left(3^{\prime}-\mathrm{CTCC}-5^{\prime}\right)$ from the canonical coordinates 


$$
\mathrm{d}(\mathrm{GAGG})+6 \mathrm{Na}^{+}+\mathrm{O}\left(\mathrm{H}_{2} \mathrm{O}\right)
$$

$$
\mathrm{d}(\mathrm{GTGG})+6 \mathrm{Na}^{+}+0\left(\mathrm{H}_{2} \mathrm{O}\right)
$$
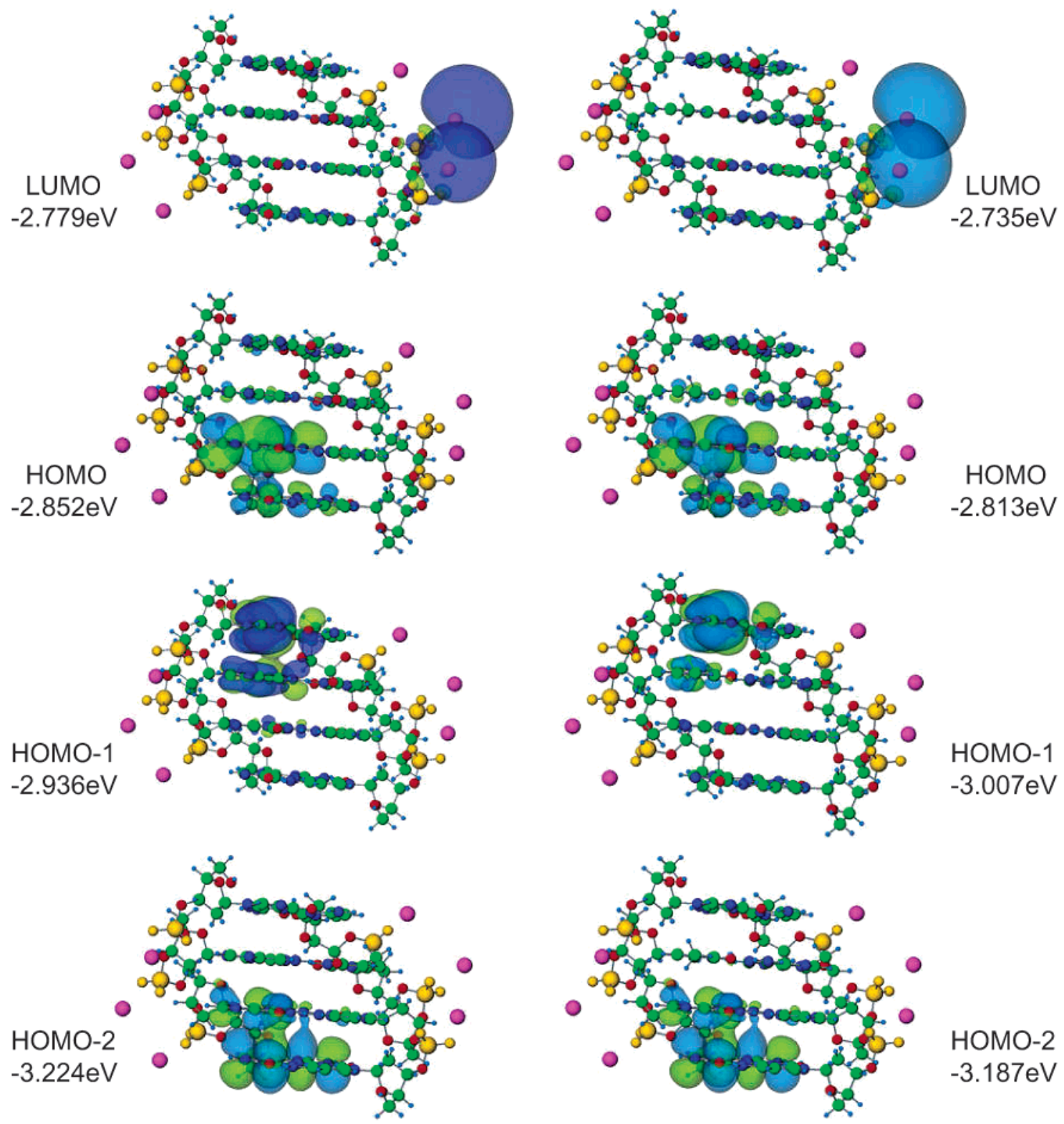

Figure 7. Isosurfaces of the LUMO and the three highest HOMO orbitals for the dehydrated d( $\left.5^{\prime}-\mathrm{GAGG}-3^{\prime}\right) \cdot \mathrm{d}\left(3^{\prime}-\mathrm{CTCC}-5^{\prime}\right)$ and d $\left(5^{\prime}-\mathrm{GTGG}-3^{\prime}\right) \cdot$ $\mathrm{d}\left(3^{\prime}-\mathrm{CACC}-5^{\prime}\right)$ duplexes. Different signs of the wavefunctions are depicted in green and blue. The corresponding eigenvalues are included. Note the localization of the LUMO on the sodium counterions.

of Arnott et al. ${ }^{25}$ Six sodium cations were added at electronegative points near the phosphate groups on the backbones and the system was placed in a periodic cell and hydrated with 1700 water molecules, with the axis of the oligomer parallel to the $z$-axis of the cell. The positions of all heavy (non-hydrogen) DNA atoms were fixed and the positions of the sodium counterions were restrained with harmonic forces [with a spring constant of $1 \mathrm{kcal} /\left(\mathrm{mol} \AA^{2}\right)$ ] to remain near the phosphate groups, as they would be in the systems we are studying. The Amber 6 program sander was used to perform a molecular dynamics simulation with an integration time step of $1 \mathrm{fs}$ and default values for other parameters, unless otherwise stated. The system was then equilibrated at $300 \mathrm{~K}$ and a pressure of $1 \mathrm{~atm}$ for over $200 \mathrm{ps}$.

Subsequently, we extracted the "minimal" cluster to use in the quantum mechanical calculations. We removed the periodic boundary conditions and all the water molecules having no atom closer than $5 \AA$ to the DNA atoms or to the cations. Next, all constraints on the sodium cations were removed and the energy of the system was minimized with only the heavy DNA atoms fixed. Using a computer graphics program to display hydrogen bonds, we repeated the process of manually winnowing away water molecules and thermal annealing to remove water molecules that are not essential to the structural stability of the remaining water network and the solvated cations. After removal of water molecules, we retested the stability of the structure by annealing it. When no clear candidates for removal remained, the remaining cluster was annealed by heating it to $150 \mathrm{~K}$ over $30 \mathrm{ps}$, followed by cooling back to $0 \mathrm{~K}$ over another $30 \mathrm{ps}$ interval (we used $150 \mathrm{~K}$ instead of $300 \mathrm{~K}$ because water in such small clusters is much more volatile than in bulk and a higher temperature obliterates the water's structure too easily). At this stage, we examined the system for a possible "collapse" of the hydrogen-bond structure. If such collapse was encountered, it 


$$
\mathrm{d}(\mathrm{GAGG})+6 \mathrm{Na}^{+}+48\left(\mathrm{H}_{2} \mathrm{O}\right) \quad \mathrm{d}(\mathrm{GTGG})+6 \mathrm{Na}^{+}+48\left(\mathrm{H}_{2} \mathrm{O}\right)
$$
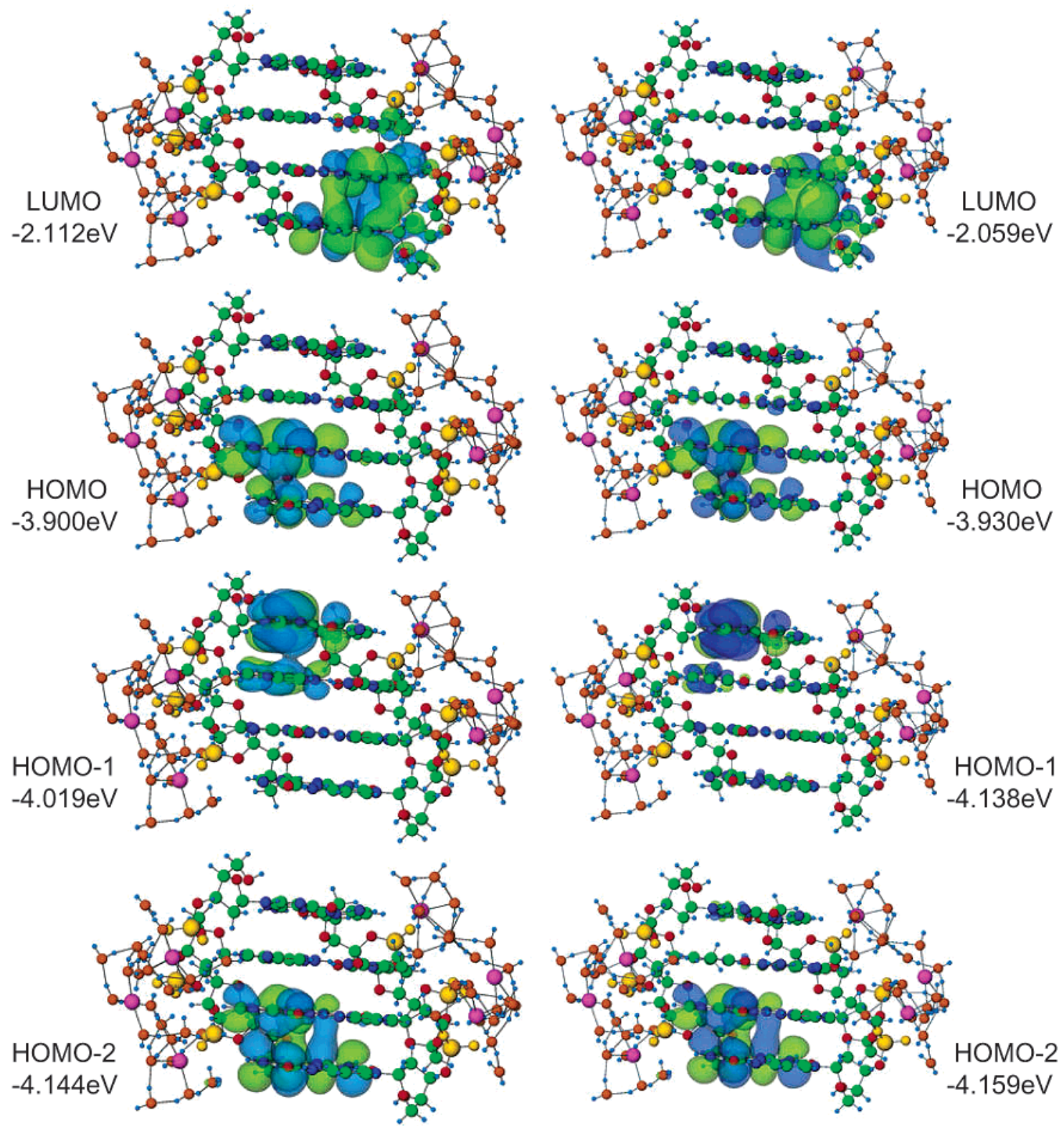

Figure 8. Isosurfaces of the LUMO and the three highest HOMO orbitals for the $\mathrm{d}\left(5^{\prime}-\mathrm{GAGG}-3^{\prime}\right) \cdot \mathrm{d}\left(3^{\prime}-\mathrm{CTCC}-5^{\prime}\right)$ and $\mathrm{d}\left(5^{\prime}-\mathrm{GTGG}-3^{\prime}\right) \cdot$ $\mathrm{d}\left(3^{\prime}\right.$-CACC-5') duplexes for $n=48$, i.e., "peripheral hydration". Note the vanishing weight of the LUMO on the counterions (compare with Figure 7).

indicated that we removed a "structural" water molecule and the previous winnowing step (or steps) was repeated. Otherwise, the search for structurally extraneous water molecules was repeated until a suitable cluster for the purposes of a density functional calculation remained. In the later stages of this process, water molecules located in the groove regions of the DNA were aggressively removed, anticipating their replacement with ones in judiciously selected positions. Eventually this process yields a cluster containing the $\mathrm{d}\left(5^{\prime}\right.$-GAGG-3') $\mathrm{d}\left(3^{\prime}\right.$-CTCC-5') oligomer with six cations near the backbone (peripheral) phosphate groups and hydrated by 48 water molecules, which is stable under short annealing simulations, with no atoms constrained in any way except the heavy DNA atoms (which must be so constrained to maintain the B-DNA structure at such low humidity).

Having constructed the DNA oligomer with a "minimal" peripheral hydration, three (and then two more) water molecules are placed in the minor groove in positions corresponding to the two deepest tiers in the spine of hydration. ${ }^{26}$ Even though this is not A-tract DNA, where the spine of hydration is commonly expected, these are still stable positions. The 12 water molecules in the major groove were placed near atoms that support hydrogen bonds, ${ }^{27}$ such as the 6-keto group and N7 of guanine, the N7 and 6-amino group of adenine, the 4-amino group of cytosine, and the 4-keto group of thymine. After each set of water molecules was added, the stability of the system was tested by a simulated annealing, as described above.

This process yields configurations of counterions and water molecules that can replace in situ the $\mathrm{d}\left(5^{\prime}-\mathrm{GAGG}-3^{\prime}\right) \cdot \mathrm{d}\left(3^{\prime}-\right.$ CTCC-5') canonical structure with $\mathrm{d}\left(5^{\prime}-\mathrm{GTGG}-3^{\prime}\right) \cdot \mathrm{d}\left(3^{\prime}-\mathrm{CACC}\right.$ $\left.5^{\prime}\right)$ and produce a system that under annealing undergoes only modest structural changes. In this manner, we constructed the $\mathrm{d}\left(5^{\prime}\right.$-GTGG-3') $\cdot \mathrm{d}\left(3^{\prime}-\mathrm{CACC}-5^{\prime}\right)$ model systems used for quantum mechanical calculations. 


$$
\mathrm{d}(\mathrm{GAGG})+6 \mathrm{Na}^{+}+65\left(\mathrm{H}_{2} \mathrm{O}\right) \quad \mathrm{d}(\mathrm{GTGG})+6 \mathrm{Na}^{+}+65\left(\mathrm{H}_{2} \mathrm{O}\right)
$$

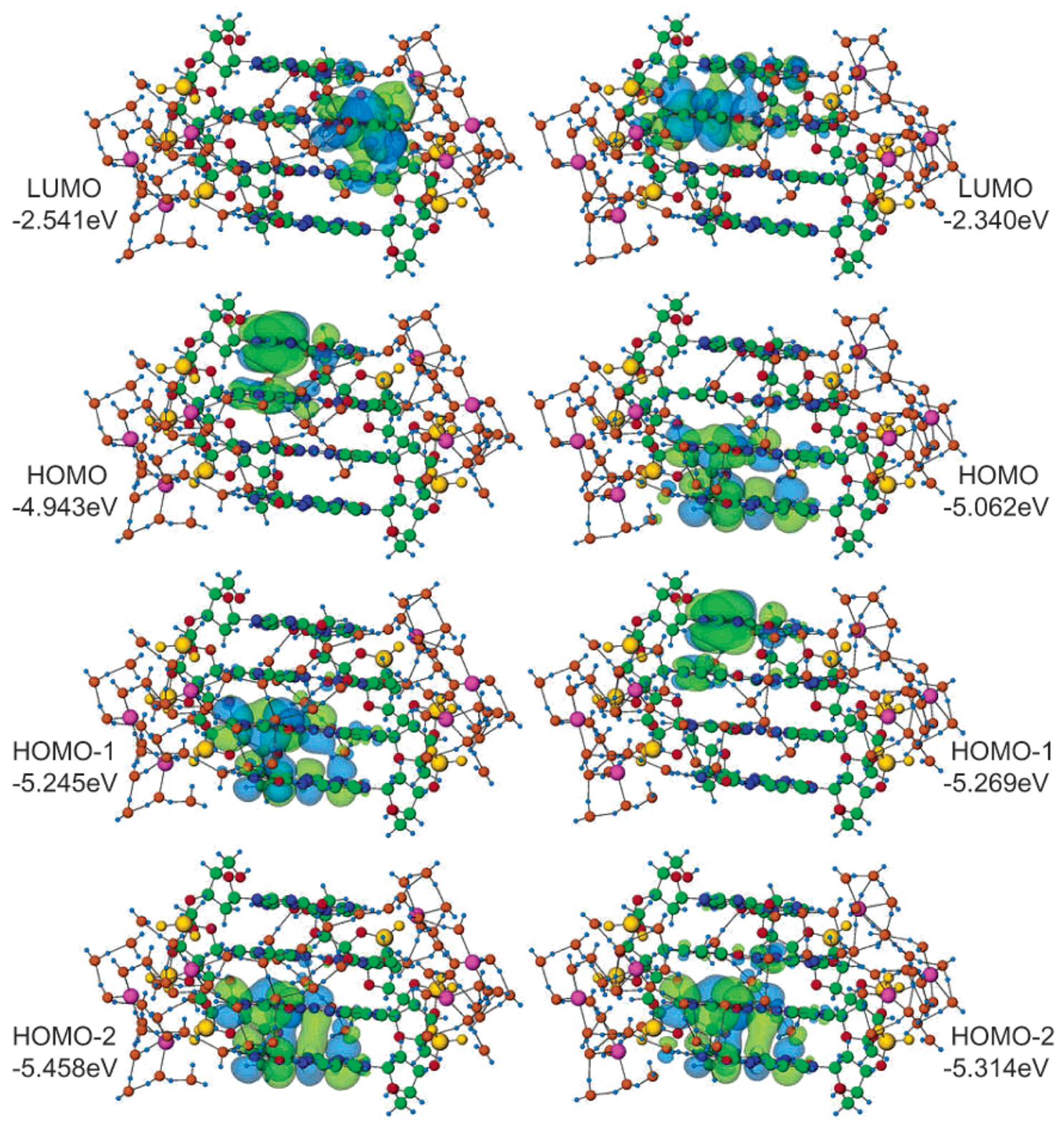

Figure 9. Isosurfaces of the LUMO and the three highest HOMO orbitals for the d( $\left.5^{\prime}-\mathrm{GAGG}-3^{\prime}\right) \cdot \mathrm{d}\left(3^{\prime}-\mathrm{CTCC}-5^{\prime}\right)$ and $\mathrm{d}\left(5^{\prime}-\mathrm{GTGG}-3^{\prime}\right) \cdot$ $\mathrm{d}\left(3^{\prime}-\mathrm{CACC}-5^{\prime}\right)$ duplexes for $n=65$, i.e. "full hydration" (backbone, counterions, and minor- and major-groove regions).

(B) Quantum Mechanical Calculations. The first-principles quantum mechanical calculations were performed by the BornOppenheimer (BO) local-spin-density (LSD) molecular dynamics (MD) method [BO-LSD-MD] ${ }^{28}$ with gradient corrections for the exchange-correlation functional. ${ }^{29}$ The Kohn-Sham equations were solved in conjunction with norm-conserving nonlocal pseudopotentials for the valence electrons ${ }^{30}$ and a plane-wave basis (i.e., no atom-centered basis functions were used) with a high kinetic energy cutoff of $845 \mathrm{eV}$; a calculation for the 4 base pair duplex d( $5^{\prime}-$ GAGG-3') $\mathrm{d}\left(3^{\prime}-\mathrm{CTCC}-5^{\prime}\right)$ with $48 \mathrm{H}_{2} \mathrm{O}$ and six $\mathrm{Na}$ comprises 1240 valence electrons. The algorithm for solving the density-functional Kohn-Sham equations uses a Fermi distribution function for the electrons, which is a very effective way of dealing with degenerate or neardegenerate energy levels. ${ }^{28}$ The Fermi temperature that we used is rather low, i.e., $0.01 \mathrm{eV} / \mathrm{k}_{\mathrm{B}}$; this ensures that the Fermi function is operative only on the nearly-degenerate levels at the top of the level spectrum and not anywhere else (where the spectral gaps are larger). The BO-LSD-MD method is particularly well-suited for calculations of charged systems since no periodic replication of the ions is imposed; that is, no supercells are employed. ${ }^{28}$

To illustrate the accuracy of the calculations we give the vertical (v) and adiabatic (a) ionization potentials (IP), calculated for the isolated nucleobases as the total energy difference between the neutral and ionized species. For T, vIP $=8.73 \mathrm{eV}$ and $\mathrm{aIP}=8.54 \mathrm{eV}$; for $\mathrm{C}$, vIP $=8.54 \mathrm{eV}$ and $\mathrm{aIP}=8.43 \mathrm{eV}$; for $\mathrm{A}, \mathrm{vIP}=8.11 \mathrm{eV}$ and $\mathrm{aIP}=7.96 \mathrm{eV}$; for $\mathrm{G}, \mathrm{vIP}=7.70 \mathrm{eV}$ and aIP $=7.20 \mathrm{eV}$. We note that the values obtained from our calculations are consistently lower by $3-6 \%$ than the measured values. ${ }^{31-33}$

\section{Results and Discussion}

(A) Experimental Studies. Shown in Chart 1 are the structures of two DNA oligomers that were prepared to test the 
TABLE 2: Energetics (in $\mathrm{eV}$ ) of the $\mathrm{d}\left(5^{\prime}-\mathrm{CTCC}-3^{\prime}\right) \cdot \mathrm{d}\left(3^{\prime}-\mathrm{GAGG}-5^{\prime}\right)$ and d $\left(5^{\prime}-C A C C-3^{\prime}\right) \cdot d\left(3^{\prime}-G T G G-5^{\prime}\right)$ Duplexes, at Various Hydration Levels, $n\left(\mathrm{H}_{2} \mathrm{O}\right)^{a}$

\begin{tabular}{|c|c|c|c|c|}
\hline & \multicolumn{4}{|c|}{$n\left(\mathrm{H}_{2} \mathrm{O}\right)$} \\
\hline & 0 & 48 & 53 & 65 \\
\hline \multicolumn{5}{|c|}{$\mathrm{d}\left(5^{\prime}-\mathrm{CTCC}-3^{\prime}\right) \cdot \mathrm{d}\left(3^{\prime}-\mathrm{GAGG}-5^{\prime}\right)$} \\
\hline$\Delta_{\mathrm{HL}}$ & $\begin{array}{l}0.073 \\
(\mathrm{G}-\mathrm{Na})\end{array}$ & $\begin{array}{l}1.79 \\
\left(\mathrm{G}-5^{\prime} \mathrm{C}\right)\end{array}$ & $\begin{array}{l}1.86 \\
\left(\mathrm{G}-5^{\prime} \mathrm{C}\right)\end{array}$ & $\begin{array}{l}2.40 \\
\left(5^{\prime} \mathrm{G}-\mathrm{T}\right)\end{array}$ \\
\hline$\Delta\left(3^{\prime} \mathrm{G}-5^{\prime} \mathrm{G}\right)$ & & & & 3.69 \\
\hline$\Delta(G-G)$ & & & & 3.55 \\
\hline$\Delta\left(3^{\prime} \mathrm{G}-3^{\prime} \mathrm{G}\right)$ & & & & 3.67 \\
\hline vIP & 4.06 & 4.73 & 5.37 & 6.24 \\
\hline \multicolumn{5}{|c|}{$\mathrm{d}\left(5^{\prime}-\mathrm{CACC}-3^{\prime}\right) \cdot \mathrm{d}\left(3^{\prime}-\mathrm{GTGG}-5^{\prime}\right)$} \\
\hline$\Delta_{\mathrm{HL}}$ & $\begin{array}{l}0.077 \\
(\mathrm{G}-\mathrm{Na})\end{array}$ & $\begin{array}{l}1.87 \\
\left(\mathrm{G}^{\prime} 5^{\prime} \mathrm{C}\right)\end{array}$ & $\begin{array}{l}2.01 \\
\left(\mathrm{G}-5^{\prime} \mathrm{C}\right)\end{array}$ & $\begin{array}{l}2.72 \\
\left(3^{\prime} \mathrm{G}-\mathrm{T}\right)\end{array}$ \\
\hline$\Delta\left(3^{\prime} \mathrm{G}-5^{\prime} \mathrm{G}\right)$ & & & & 3.61 \\
\hline$\Delta(\mathrm{G}-\mathrm{G})$ & & & & 3.61 \\
\hline$\Delta\left(3^{\prime} \mathrm{G}-3^{\prime} \mathrm{G}\right)$ & & & & 3.62 \\
\hline vIP & 3.87 & 5.17 & 5.63 & 6.28 \\
\hline
\end{tabular}

${ }^{a}$ The HOMO-LUMO energy gap $\left(\Delta_{\mathrm{HL}}\right)$ is given with the spatial locations of the HOMO and LUMO orbitals (see parentheses under the numerical values). The smallest energy gaps between occupied and unoccupied orbitals both lying on the same base are denoted by $\Delta(\mathrm{X}$ $-\mathrm{X}$ ), with $\mathrm{X}=5^{\prime} \mathrm{G}, \mathrm{G}$, and $3^{\prime} \mathrm{G}$; all of the $\pi \pi^{*} \mathrm{G}$-gaps are of the order of $3.6 \mathrm{eV}$. Note that for the isolated $\mathrm{G}$, the corresponding calculated value is $3.85 \mathrm{eV}$, indicating a relative weak perturbation due the incorporation of the base into the DNA duplex. The vertical ionization potentials (vIP) are given at the bottom.
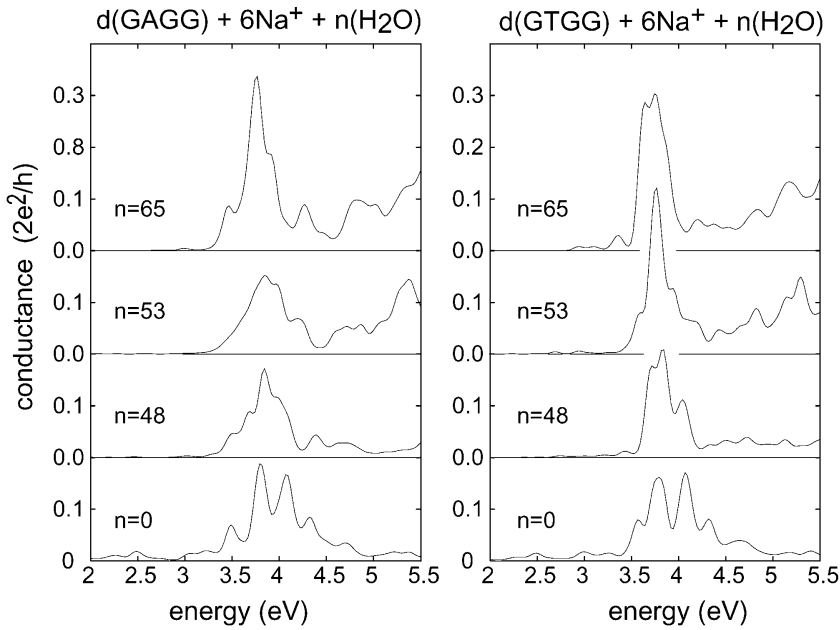

Figure 10. Optical conductances (in units of the conductance quantum $2 \mathrm{e}^{2} / h$, where $\mathrm{e}$ is the electron charge and $h$ is Planck's constant), which are proportional to the optical absorption spectra, calculated by use of the Kubo relation (eq 1). Results are shown for various hydration levels of the two DNA oligomers. Observe the similarity in peak positions and overall line shapes for the two oligomers. Note that the spectra calculated for "dry" DNA show finite values for energies in the range of $2-3.25 \mathrm{eV}$, which vanish even at the lowest hydration level.

effect of conversion of the probe sequence d( $\left.5^{\prime}-\mathrm{GAGG}-3^{\prime}\right) \cdot$ $\mathrm{d}\left(3^{\prime}-\mathrm{CTCC}-5^{\prime}\right)$ to $\mathrm{d}\left(5^{\prime}-\mathrm{GTGG}-3^{\prime}\right) \cdot \mathrm{d}\left(3^{\prime}-\mathrm{CACC}-5^{\prime}\right)$ on the migration of a base radical cation. Each DNA oligomer has an anthraquinone (AQ) derivative covalently linked to a $5^{\prime}$ terminus, three $\left(\mathrm{C}^{\cdot} \cdot \mathrm{G}\right)_{2}$ steps, and is labeled at a $3^{\prime}$-terminus with ${ }^{32} \mathrm{P}$ at cytosine, which is indicated by $\mathrm{C}^{*}$. The absorption spectra of these DNA oligomers are shown in Figure 1. Irradiation of the AQ at $350 \mathrm{~nm}$ (where the DNA bases do not absorb significantly) forms the AQ singlet excited state, which rapidly intersystem crosses to its triplet state $(A Q * 3) .{ }^{34}$ One-electron oxidation of the DNA by the $\mathrm{AQ}^{* 3}$ forms a base radical cation $\left(\mathrm{B}^{+\bullet}\right)$ and converts the $\mathrm{AQ}^{* 3}$ to its radical anion $\left(\mathrm{AQ}^{-} \cdot\right)$. Because this electron-transfer reaction originated with a triplet

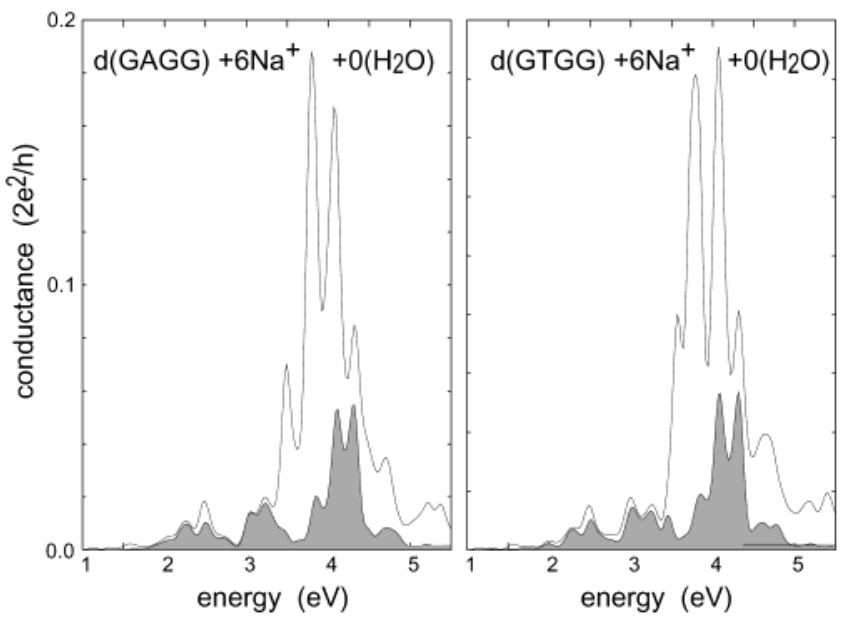

Figure 11. Optical conductances calculated for the "dry" DNA oligomers, with contributions to the spectra originating from transition matrix elements (see eq 1) between occupied orbitals located on the DNA and unoccupied orbitals located on the counterions, identified by the gray shaded regions. It is evident that the aforementioned lowenergy tail of the optical spectra derives almost entirely from such transitions, which are absent upon hydration (see Figure 10).

state of $\mathrm{AQ}$, the radical ion pair is formed as an overall triplet, $\left(\mathrm{AQ}^{-} \cdot-\mathrm{B}^{+} \cdot\right)^{3}$, which gives it a lifetime sufficiently long for reaction of $\mathrm{AQ}^{-} \cdot$ with $\mathrm{O}_{2}$ to form superoxide $\left(\mathrm{O}_{2}^{-\bullet}\right)$. This leaves the base radical cation without a partner for annihilation and provides time for it to hop through the DNA before reacting with water or $\mathrm{O}_{2}{ }^{4,35}$ These processes are summarized in Scheme 1 .

Irradiation of $5 \mu \mathrm{M}$ solutions of AQ-DNA(1) or AQ-DNA(2) for $2 \mathrm{~min}$ at ca. $30{ }^{\circ} \mathrm{C}$ in phosphate buffer at $\mathrm{pH} 7.0$ causes reaction predominantly at the $5^{\prime}$-guanines of the $(\mathrm{C} \cdot \mathrm{G})_{2}$ steps that is revealed as strand breaks by treatment of the samples with hot piperidine. The amount of reaction at each of the $(\mathrm{C} \cdot \mathrm{G})_{2}$ steps is determined by polyacrylamide gel electrophoresis (PAGE), visualized by autoradiography, and quantitated by phosphorimagery. The autoradiograms from these experiments are shown in Figure 2, and the results of the phosphorimagery are shown in Table 1 in terms of the ratio of reactivity (strand cleavage $)$ at $5^{\prime}-\left(\mathrm{C} \cdot \mathrm{G}_{1}\right)$ to $5^{\prime}-\left(\mathrm{C} \cdot \mathrm{G}_{n}\right)$. Clearly, conversion of the $\mathrm{T} \cdot \mathrm{A}$ base pair of AQ-DNA(1) to $\mathrm{A} \cdot \mathrm{T}$ in AQ-DNA(2) has no measurable effect on the efficiency of radical cation transport. This conclusion does not necessarily contradict the kinetic measurements of Lewis and Wasielewski and co-workers, ${ }^{15}$ since our measurements pertain to equilibrium conditions. Moreover, equilibrium measurements depend both on the rate of the radical cation transport process and on the rates of competing reaction. In the experiments reported here, the competing reaction is trapping of the radical cation with water, whereas in the Lewis and Wasielewski experiments, the competing reaction is return electron transfer.

(B) Theoretical Results. One part of this study is directed at elucidation of sequence effects on the electronic and hole transport properties of DNA; specifically, the effect of changing an $\mathrm{A} \cdot \mathrm{T}$ base pair to $\mathrm{T} \cdot \mathrm{A}$ in duplexes containing the segments $\mathrm{d}\left(5^{\prime}-\mathrm{GAGG}-3^{\prime}\right) \cdot \mathrm{d}\left(3^{\prime}-\mathrm{CTCC}-5^{\prime}\right)$ and $\mathrm{d}\left(5^{\prime}-\mathrm{GTGG}-3^{\prime}\right) \cdot$ $\mathrm{d}\left(3^{\prime}-\mathrm{CACC}-5^{\prime}\right)$. A second part of this study is the systematic exploration of the dependencies of these properties (and sequence effects) on the degree of hydration of these DNA oligomers. To this aim, we performed comparative theoretical investigations of the electronic properties, calculated at various levels of hydration (see Figure 3 ). We describe results for the duplexes d $\left(5^{\prime}-\mathrm{CXCC}-3^{\prime}\right) \cdot \mathrm{d}\left(3^{\prime}-\mathrm{GXGG}-5^{\prime}\right)+6 \mathrm{Na}^{+}+n\left(\mathrm{H}_{2} \mathrm{O}\right)$, where $\mathrm{X}=\mathrm{A}$ or $\mathrm{T}$ in a Watson-Crick base pair, and the sodium 


$$
\left[\mathrm{d}(\mathrm{GAGG})+6 \mathrm{Na}+65\left(\mathrm{H}_{2} \mathrm{O}\right)\right]^{+}
$$

$$
\left[\mathrm{d}(\mathrm{GTGG})+6 \mathrm{Na}+65\left(\mathrm{H}_{2} \mathrm{O}\right)\right]^{+}
$$
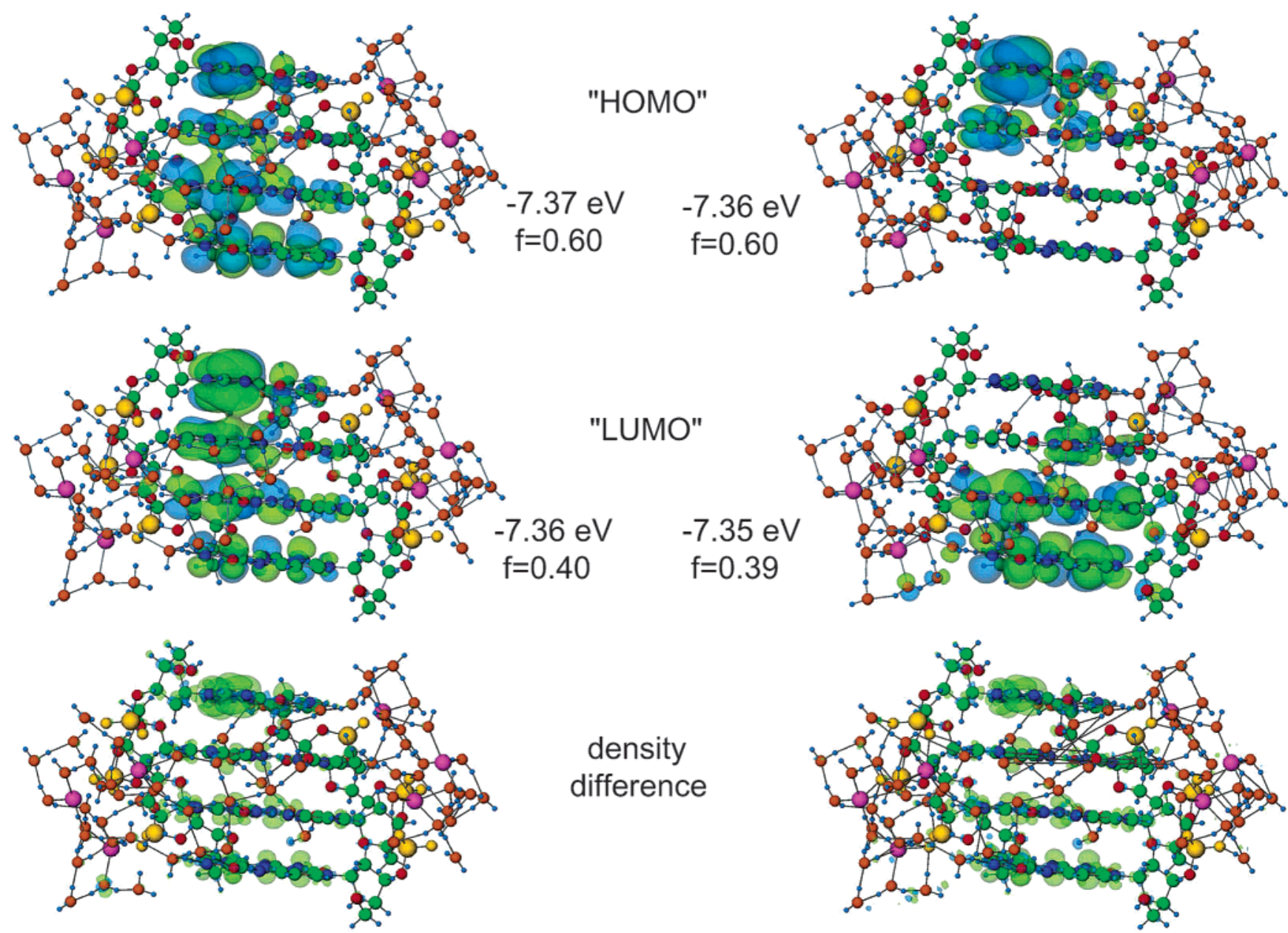

Figure 12. Top and middle panels: Isosurfaces of the two degenerate orbitals at the top of the occupied electronic eigenvalue spectrum of the vertically ionized fully hydrated oligomers. The orbitals exhibit partial occupations and are therefore denoted as "HOMO" and "LUMO". The green and blue colors of the isosurfaces correspond to different signs of the wave functions. Bottom panel: Electron density difference between the neutral and vertically ionized DNA duplexes, portraying the spatial distribution of the electron hole.

cations are located near the sugar-phosphate groups of the DNA backbone. In particular we focus on the following systems: (i) $n=0$, that is, an unhydrated duplex; (ii) $n=48$, where the water molecules hydrate the backbone (including the sodium counterions) of the DNA oligomer; (iii) $n=53$, where in addition to the hydration of the sugar-phosphate backbone, five additional $\mathrm{H}_{2} \mathrm{O}$ molecules hydrate the minor groove of the DNA duplex; and (iv) $n=65$, where further hydration of the DNA major groove (involving 12 additional water molecules) is considered. These configurations (see Figure 3) are designed to model the "minimal" hydration environments of the DNA sugar-phosphate backbone and of the minor- and major-groove regions.

In Figure 4, we display the distributions of interaction energies between the $\mathrm{H}_{2} \mathrm{O}$ molecules and the various components of the DNA sequences (i.e., the DNA bases, the sugar-phosphate backbones, and the sodium counterions). We observe that the water molecules hydrating the minor and major grooves $\left(\mathrm{W}_{\mathrm{m}}\right.$ and $\mathrm{W}_{\mathrm{M}}$, respectively) interact more strongly with the DNA bases than do the (peripheral) water molecules hydrating the DNA sugar-phosphate backbone regions (see $\mathrm{W}_{\mathrm{B}}$ in the top panel of Figure 4). On the other hand, the $\mathrm{H}_{2} \mathrm{O}$ molecules hydrating the sugar-phosphate backbone (see middle and bottom panels of Figure 4) interact relatively strongly with the sugar-phosphate atoms and with the sodium counterions.
Finally, the histograms in Figure 5 show that the distribution of hydration interaction energies corresponding to the $\mathrm{d}\left(5^{\prime}\right.$ GAGG-3') $\cdot \mathrm{d}\left(3^{\prime}-\mathrm{CTCC}-5^{\prime}\right)$ and $\mathrm{d}\left(5^{\prime}-\mathrm{GTGG}-3^{\prime}\right) \cdot \mathrm{d}\left(3^{\prime}-\mathrm{CACC}-5^{\prime}\right)$ duplexes are rather similar.

The local densities of states (LDOS) of the electronic eigenvalue spectra for various hydration levels of the $\mathrm{d}\left(5^{\prime}\right.$ GAGG-3') $\cdot \mathrm{d}\left(3^{\prime}-\mathrm{CTCC}-5^{\prime}\right)$ and d( $\left.5^{\prime}-\mathrm{GTGG}-3^{\prime}\right) \cdot \mathrm{d}\left(3^{\prime}-\mathrm{CACC}-5^{\prime}\right)$ oligomers are shown in Figure 6. These plots [where the highest occupied molecular orbitals (HOMO) are marked in red, and the lowest unoccupied molecular orbital (LUMO) is marked in green] provide information about the weight of orbitals (corresponding to electronic levels with energies at a given range) at various spatial regions. That is, the heights of the vertical bars at the various energies (on the horizontal axis) indicate the probabilities of finding electrons that occupy orbitals at particular spatial regions of the DNA, including the nuclear bases (marked by their names and their location in the duplex, when applicable, i.e., 5'-G, A, G, 3'-G, etc.), the sugarphosphate backbone, the $\mathrm{Na}^{+}$counterions, and the water molecules in the minor groove and those in the major groove. Corresponding isosurfaces of the LUMO and the three highest HOMO orbitals for the various hydration levels of the two DNA oligomers are shown in Figures 7-9.

Inspection of the LDOS in Figure 6 and the values given in Table 2 reveals several trends pertaining to the energetics and 

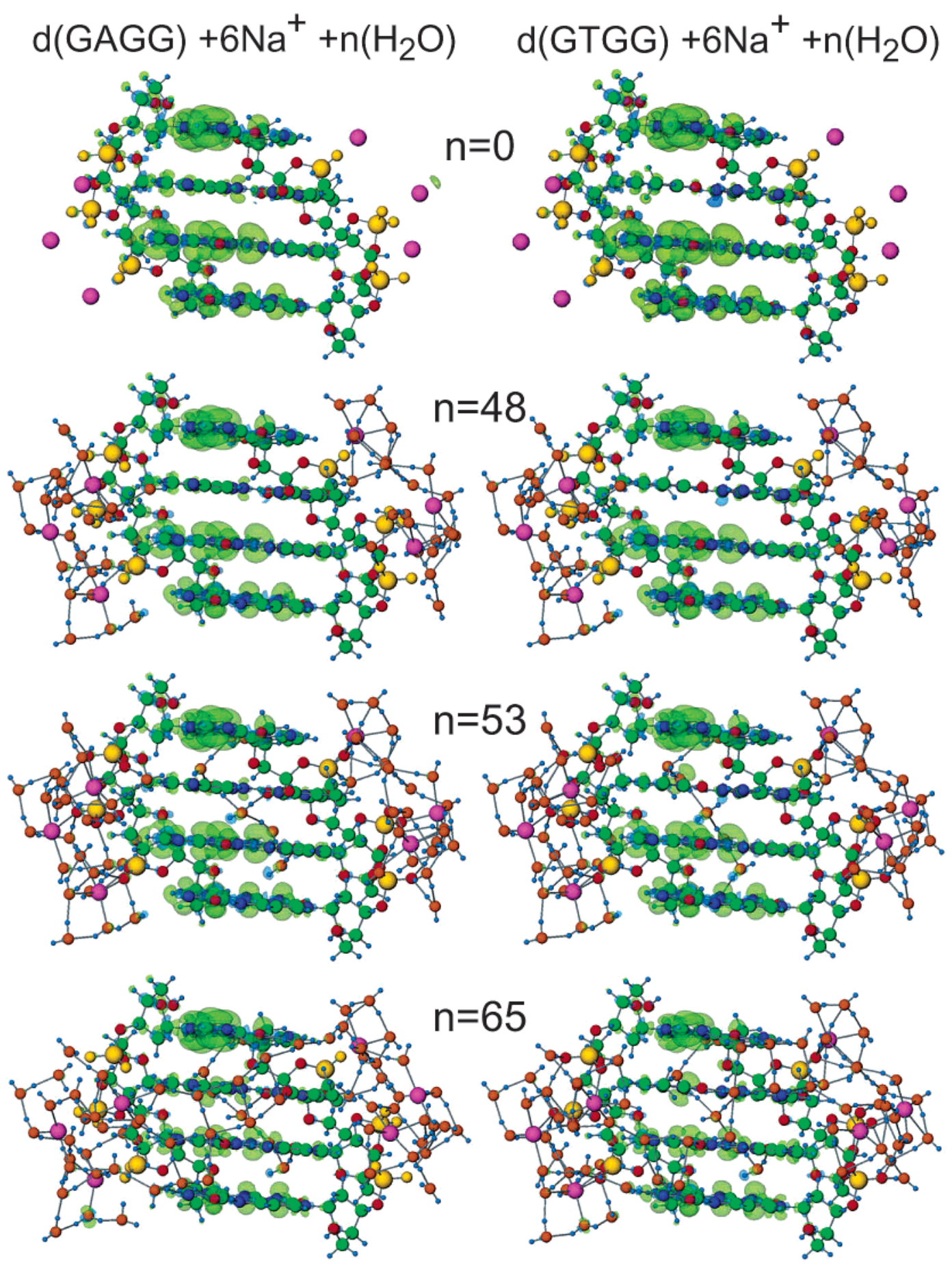

Figure 13. Electron density difference between the neutral and vertically ionized DNA duplexes, for various hydration levels $(n=0,48,53$, and 65). Note that the hole distributions of the two oligomers appear rather similar and they are independent of the level of hydration.

spatial distribution of the wave functions in the DNA oligomers and the effects of hydration on these properties:

(i) The LDOS for the dry (dehydrated) DNA shows that the HOMO orbitals reside mainly on the guanine base and the LUMO orbital is distributed on the counterions (see top panels of Figures 6 and 7), with the HOMO - LUMO gap $\left(\Delta_{\mathrm{HL}}\right)$ being rather small (i.e., about $0.075 \mathrm{eV}$, see Table 2); these results are similar for both $\mathrm{d}\left(5^{\prime}-\mathrm{GAGG}-3^{\prime}\right) \cdot \mathrm{d}\left(3^{\prime}-\mathrm{CTCC}-5^{\prime}\right)$ and $\mathrm{d}\left(5^{\prime}-\mathrm{GTGG}-3^{\prime}\right) \cdot \mathrm{d}\left(3^{\prime}-\mathrm{CACC}-5^{\prime}\right)$ duplexes.

(ii) Hydration of the DNA influences the eigenvalue spectra, shifting the occupied orbitals to more negative (increased binding) values and increasing gradually $\Delta_{\mathrm{HL}}$.

(iii) Hydration causes the LUMO orbital (and the rest of the unoccupied eigenfunctions) to localize on the DNA bases (with negligible weights on the counterions; see Figures 6, 8, and 9), and increasing the hydration level decreases the probability for finding the LUMO orbitals on the sugar-phosphate backbone atoms and backbone hydrating molecules.

(iv) The smallest energy gap between occupied and unoccupied orbitals both having substantial weights on the same DNA base [i.e., $\pi \pi^{*}$ excitation $\Delta\left(5^{\prime} \mathrm{G}-5^{\prime} \mathrm{G}\right), \Delta(\mathrm{G}-\mathrm{G})$, and $\Delta\left(3^{\prime} \mathrm{G}-3^{\prime} \mathrm{G}\right)$ in Table 2] are of the order of 3.6-3.7 eV for both oligomers under full hydration conditions $\left[n\left(\mathrm{H}_{2} \mathrm{O}\right)=65\right]$. Note that for the isolated guanine $(\mathrm{G})$ our calculated value of the $\pi \pi^{*}$ energy gap is $3.85 \mathrm{eV}$, indicating a relative weak perturbation due the incorporation of the base into the DNA duplex. Such energy gaps are known to be systematically underestimated by DFT theory (by ca. $1 \mathrm{eV}$ ). 


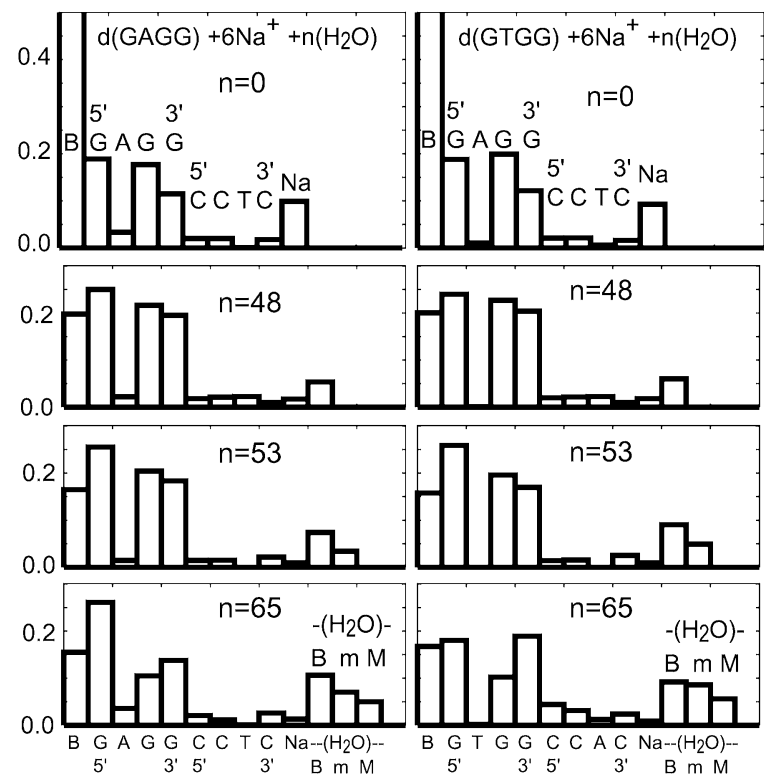

Figure 14. Histograms of the spatial distribution of the electron density differences (see Figure 13); that is, the spatial distribution of the hole formed by vertical ionization. For "dry" DNA [i.e., $n\left(\mathrm{H}_{2} \mathrm{O}\right)=0$ ] a significant portion of the hole distribution resides on the counterions (marked $\mathrm{Na}^{+}$) and sugar-phosphate backbones (B), while upon hydration it vanishes on the counterions and diminishes on the sugarphosphate backbone atoms. Different regions corresponding to the hydration environment are distinguished as $\mathrm{B}, \mathrm{m}$, and $\mathrm{M}$, corresponding to $\mathrm{H}_{2} \mathrm{O}$ molecules hydrating the backbone and minor- and major-groove regions, respectively.

(v) The vertical ionization potentials are strongly dependent on the hydration level and upon hydration of the sugarphosphate backbone, counterions, and minor-groove as well as major-groove regions of the DNA. These quantities converge to very similar values for the two oligomers (about $6.2 \mathrm{eV}$; see Table 2).

Certain aspects of the trends exhibited by the eigenvalue spectra are portrayed by the optical conductance (which is proportional to the optical absorption spectrum) calculated by using the Kubo-Greenwood expression: ${ }^{36,37}$

$$
G_{\alpha \alpha}(\omega)=\frac{2 \pi \mathrm{e}^{2} \hbar}{3 m_{\mathrm{e}} L_{\alpha}{ }^{2}} \sum_{i, j}\left(f_{i}-f_{j}\right) \frac{\left|\left\langle i\left|\hat{\boldsymbol{p}}_{\alpha}\right| \boldsymbol{j}\right\rangle\right|^{2}}{\epsilon_{\boldsymbol{i}}-\epsilon_{j}} \boldsymbol{\delta}\left(\epsilon_{\boldsymbol{i}}-\epsilon_{j}-\boldsymbol{\omega}\right)
$$

where $\alpha$ is the direction $x, y$, or $z ; m_{\mathrm{e}}$ is the electron mass, $L_{\alpha}$ is the length of the calculational cell in the $\alpha$ direction, $f_{i}$ is the occupation and $\epsilon_{i}$ is the energy of the $i$ th wave function, and $\hat{p}_{\alpha}$ is the momentum operator $-i \hbar \delta / \delta r_{\alpha}$. In the calculation the delta function is replaced by a Gaussian of width $0.05 \mathrm{eV}$, and the average conductance $G(\omega)=1 /{ }_{3} \Sigma_{\alpha} G_{\alpha \alpha}(\omega)$ is shown in Figure 10 for various degrees of hydration for the two DNA oligomers. We observe a similarity in the peak positions and overall line shapes for the two oligomers and a strong dependence on the hydration level. In particular, we note that the spectra calculated for dry DNA show finite values for energies in the range of $2-3.25 \mathrm{eV}$, which vanish at even the lowest $\left[n\left(\mathrm{H}_{2} \mathrm{O}\right)=48\right]$ hydration level (compare the bottom two panels in Figure 10). To explore this dependence further, we show in Figure 11 the optical conductances calculated for dry DNA oligomers, with contributions to the spectra originating from transition matrix elements (see eq 1 ) between occupied orbitals located on the DNA and unoccupied orbitals located on the counterions, identified by the gray shaded regions. It is evident that the aforementioned low-energy tail of the optical spectra is derived almost entirely from such transitions, which are absent upon hydration (see discussion in connection with the electronic LDOS in Figure 6 and the orbital portraits in Figures 7-9). Consequently, we conclude that inappropriate positioning of the counterions, and/or improper hydration of the counterions, give erroneous results for the optical conductivity (or, equivalently, the optical spectrum), and other properties of DNA (particularly those related to the energies and spatial distributions of the electronic eigenvalues). ${ }^{38}$ This finding is entirely consistent with the experimental spectra of the oligomers studied here and reported above and with the well-known spectrum of duplex DNA generally. ${ }^{39}$

Finally, we address certain issues related to the formation of an electron hole in the two oligomers investigated here. It is clear that the vertical ionization potentials of these duplexes show a strong dependence on their hydration levels, which converge to a similar value (ca. $6.25 \mathrm{eV}$ ) for the highest hydration level of the two oligomers (see vIP in Table 2). It is important to note that this value (and even more so for lower hydration levels) differs significantly from the vIP of the individual (isolated) bases, e.g., $\operatorname{vIP}(\mathrm{G})=7.70 \mathrm{eV}$. The isosurfaces displayed at the top and middle panels of Figure 12 show that two orbitals at the top of the occupied electronic eigenvalue spectrum of the vertically ionized oligomers are degenerate (with essentially identical eigenvalues for the two oligomers). These orbitals exhibit partial occupations and are therefore denoted as "HOMO" and "LUMO", and the true highest and lowest molecular orbitals may be formed from linear combinations of those shown here.

The electron density difference between the neutral and vertically ionized DNA duplexes, which portrays the spatial distribution of the hole for the highest hydration level of the two oligomers, is shown at the bottom of Figure 12. Visual inspection reveals the similarity between the hole distributions for the two oligomers, with the hole being delocalized on the DNA bases of the GAGG (or GTGG) strand of the duplex, with a somewhat larger weight on the 5'-G region. Interestingly, while the vIP values do exhibit a pronounced dependence on the hydration level, and they differ for the $\mathrm{d}\left(5^{\prime}-\mathrm{GAGG}-3^{\prime}\right)$. $\mathrm{d}\left(3^{\prime}-\mathrm{CTCC}-5^{\prime}\right)$ and $\mathrm{d}\left(5^{\prime}-\mathrm{GTGG}-3^{\prime}\right) \cdot \mathrm{d}\left(3^{\prime}-\mathrm{CACC}-5^{\prime}\right)$ duplexes at less than the highest hydration level studied, the hole distributions of the two oligomers appear rather similar and they are independent of the level of hydration (see Figure 13). A more quantitative analysis (see Figure 14) shows that for dry DNA [i.e., $n\left(\mathrm{H}_{2} \mathrm{O}\right)=0$ ] a significant portion of the hole resides on the counterions and sugar-phosphate backbones, while upon hydration it vanishes on the counterions and diminishes on the backbone atoms. On the other hand, the hole formed by vertical ionization is predicted to be on the hydrating water molecules with a relatively small but finite probability. As mentioned above, the hole is delocalized over the d(GAGG) [or d(GTGG)] strands of the duplexes, with somewhat larger weight on the $5^{\prime}-\mathrm{G}$ region ${ }^{40}$ (see panels for $n=53$ and 65 in Figure 14).

\section{Conclusions}

The experimental findings reported here confirm long-distance radical cation transport in duplex DNA initiated by irradiation of a covalently linked anthraquinone derivative. The radical cation migrates to and through $(\mathrm{G} \cdot \mathrm{C})_{2}$ steps where it reacts to form oxidation products that are revealed by strand cleavage after treatment with piperidine. Within experimental error, the efficiency of radical cation migration is unaffected by changing the probe sequence from $\mathrm{d}\left(5^{\prime}-\mathrm{GAGG}-3^{\prime}\right) \cdot \mathrm{d}\left(3^{\prime}-\mathrm{CTCC}-5^{\prime}\right)$ to $\mathrm{d}\left(5^{\prime}-\mathrm{GTGG}-3^{\prime}\right) \cdot \mathrm{d}\left(3^{\prime}-\mathrm{CACC}-5^{\prime}\right)$. Moreover, we showed that the 
lowest energy optical transition of DNA(1) and DNA(2) occurs at ca. $4 \mathrm{eV}$ and corresponds primarily to the $\pi \pi^{*}$ transition of the DNA bases, which is the expected result.

The theoretical findings support and extend the experimental results. The essentially identical vIP values calculated for the hydrated DNA oligomers d( $\left.5^{\prime}-\mathrm{GAGG}-3^{\prime}\right) \cdot \mathrm{d}\left(3^{\prime}-\mathrm{CTCC}-5^{\prime}\right)$ and $\mathrm{d}\left(5^{\prime}-\mathrm{GTGG}-3^{\prime}\right) \cdot \mathrm{d}\left(3^{\prime}-\mathrm{CACC}-5^{\prime}\right)$ and the similarity of their hole distributions is in agreement with the radical cation transport characteristics determined experimentally. In addition, the calculations highlight the effects of hydration on the electronic and optical properties of these sequences. The ionization potential and radical cation distribution of the DNA are strongly dependent on the extent of hydration. Meaningful results that can be compared with experiments carried out in solution are obtained only after carefully considering the placement of the sodium counterions and solvating water molecules. In particular, calculations on dry DNA produce phantom low-energy optical transitions to orbitals of the counterions that vanish even at the lowest level of hydration we examined.

Acknowledgment. This work was supported by the National Science Foundation (G.B.S.) and the U.S. Department of Energy (U.L.), for which we are grateful. Calculations were performed at the Georgia Institute of Technology Center for Computational Material Science and at the National Energy Research Scientific Supercomputing Center (NERSC) at Lawrence Berkeley, California.

\section{References and Notes}

(1) Saito, I.; Takayama, M.; Sugiyama, H.; Nakatani, K.; Tsuchida, A.; Yamamoto, M. J. Am. Chem. Soc. 1995, 117, 6406-6407. 249.

(2) Kelley, S. O.; Barton, J. K. Met. Ions Biol. Syst. 1999, 36, 211-

(3) Giese, B. Acc. Chem. Res. 2000, 33, 631-636.

(4) Schuster, G. B. Acc. Chem. Res. 2000, 33, 253-260.

(5) Brown, T.; Hunter, W. N.; Kneale, G.; Kennard, O. Proc. Natl. Acad. Sci. U.S.A. 1986, 83, 2402.

(6) Murphy, C. J.; Arkin, M. R.; Jenkins, Y.; Ghatlia, N. D.; Bossman, S. H.; Turro, N. J.; Barton, J. K. Science 1993, 262, 1025-1029.

(7) Priyadarshy, S.; Risser, S. M.; Beratan, D. N. J. Phys. Chem. 1996, 100, 17678-17682.

(8) Lincoln, P.; Tuite, E.; Norden, B. J. Am. Chem. Soc. 1997, 119, $1454-1455$

(9) Debije, M. G.; Milano, M. T.; Bernhard, W. A. Angew. Chem., Int. Ed. 1999, 38, 2752-2756.

(10) Wan, C. Z.; Fiebig, T.; Schiemann, O.; Barton, J. K.; Zewail, A. H. Proc. Natl. Acad. Sci. U.S.A. 2000, 97, 14052-14055.

(11) Jortner, J.; Bixon, M.; Langenbacher, T.; Michel-Beyerle, M. E. Proc. Natl. Acad. Sci. U.S.A. 1998, 95, 12759-12765.

(12) Gasper, S. M.; Schuster, G. B. J. Am. Chem. Soc. 1997, 119 $12762-12771$.
(13) Giese, B.; Amaudrut, J.; Kohler, A.; Sporman, M.; Wessely, S. Nature 2001, 412, 318-320.

(14) Meggers, E.; Michel-Beyerle, M. E.; Giese, B. J. Am. Chem. Soc. 1998, 120, 12950-12955.

(15) Lewis, F. D.; Zuo, X.; Hayes, R. T.; Wasielewski, M. R. J. Am. Chem. Soc. 2002, 124, 4568-4569.

(16) Henderson, P. T.; Jones, D.; Hampikian, G.; Kan, Y.; Schuster, G. B. Proc. Natl. Acad. Sci. U.S.A. 1999, 96, 8353-8358.

(17) Nunez, M.; Hall, D. B.; Barton, J. K. Chem. Biol. 1999, 6, 85-97.

(18) Williams, T. T.; Odom, D. T.; Barton, J. K. J. Am. Chem. Soc. 2000, 122, 9048-9049.

(19) Voityuk, A. A.; Rosch, N.; Bixon, M.; Jortner, J. J. Phys. Chem. B 2000, 104, 9740-9745.

(20) Sartor, V.; Boone, E.; Schuster, G. B. J. Phys. Chem. B. 2001 105, 11057-11059.

(21) Troisi, A.; Giorgio Orlandi, G. J. Chem. Phys. B. 2002, 106, 20932101.

(22) Barnett, R. N.; Cleveland, C. L.; Joy, A.; Landman, U.; Schuster, G. B. Science 2001, 294, 567-571.

(23) Case, D. A.; Perlman, D. A.; Caldwell, J. W.; Cheatham, T. E., III; Ross, W. S.; Simmerling, C. L.; Darden, T. A.; Merz, K. M.; Stanton, R. V.; Cheng, A. L.; Vincent, J. J.; Crowley, M.; Tsui, V.; Radmer, R. J.; Duan, Y.; Pitera, J.; Massova, I.; Seibel, G. L.; Singh, U. C.; Weiner, P. K.; Kollman, P. A. Amber 6: University of California, San Francisco, CA, 1999.

(24) Kollman, P. A.; Dixon, R.; Cornell, W.; Fox, T.; Chipot, C.; Pohorille, A. Computer Simulations of Biomolecular Systems; Elsevier: Amsterdam, 1997; Vol. 3.

(25) Arnott, S., et al. Atomic Coordinates and Molecular Conformations for DNA-DNA, RNA-RNA, and DNA-RNA Helices; Fasman, G. D., Ed. CRC Press: Boca Raton, FL, 1997.

(26) Subramanian, P. S.; Swaminathan, S.; Beverage, D. L. J. Biomol. Struct. Dyn. 1990, 1161-1165.

(27) Auffinger, P.; Westhof, E. J. Mol. Biol. 2000, 1113-1131.

(28) Barnett, R. N.; Landman, U. Phys. Rev. B 1993, 48, 2081.

(29) Perdew, P. P. Phys. Rev. Lett. 1996, 77, 3865.

(30) Troullier, N.; Martins, J. J. Phys. Rev. B. 1991, 43, 1993.

(31) Orlov, V. M.; Smirnov, A. N.; Varshvsky, Y. M. Tetrahedron Lett 1976, 48, 4377.

(32) Lias, S. G.; Bartness, J. E.; Liebman, J. F.; Holmes, L. J.; Levin, R. D.; Mallard, W. G. J. Phys. Chem. Ref. Data 1988, 17 (Suppl. 1), 1-861.

(33) Hush, N. S.; Cheung, A. S. Chem. Phys. Lett. 1975, 34, 11.

(34) Chouduri, J.; Roy, A.; Aditya, S. J. Indian Chem. Soc. 1986, 63 $60-63$

(35) Ly, D.; Kan, Y.; Armitage, B.; Schuster, G. B. J. Am. Chem. Soc. 1996, $118,8747-8748$

(36) Greenwood, D. A. Proc. Phys. Soc. (London), 1958, 71, 585

(37) Kubo, R. J. Phys. Soc. Jpn. 1957, 12, 570.

(38) Gervasio, F. L.; Carloni, P.; Parrinello, M. Phys. Rev. Lett. 2002, 89, 108102-1-108102-4.

(39) Bloomfield, V. A.; Crothers, D. M.; Tinoco, I., Jr. Nucleic Acids: Structure, Properties, and Function; University Science Books: Sausalito, CA, 1999.

(40) The details of the hole distribution depend on the specific counterion configuration, as illustrated in our earlier study (see ref 22). In the present work, we focused only on the configuration with all the counterions associated backbone phosphate groups. 